\title{
DINAMIKA TOTAL FACTOR PRODUCTIVITY INDUSTRI BESAR DAN SEDANG INDONESIA
}

\author{
Ndari Surjaningsih \\ Bayu Panji Permono ${ }^{7}$
}

\begin{abstract}
This paper calculates and decomposes the Total Factor Productivity (TFP) for large and medium scale industry in Indonesia covering the period of 2000-2009. By using Data Envelopment Analysis (DEA) method, the result shows there is a shift of the supporting factors on the growth of TFP on manufacturing sector within the 2 (two) sample period. In the period of 2000-2004, efficiency change becomes the main contributor on the growth of TFP. Whereas in the period of 2005-2009, technical change becomes the main supporting factor of TFP, however it goes along with the growth of negative efficiency change or the decline of the company's catching-up effect ability to adapt with the more advance technology. The grouping of the sample across subsectors, technical change and also efficiency change shows the declining amount of manufacture industry with superior productivity. Furthermore, the number of low and weakening catching-up industry is increasing.
\end{abstract}

Keywords: Indonesian manufacturing, total factor productivity, technical change, efficiency change, economic scale change, Data Envelopment Analysis

JEL Classification: L6, M11

1 Authors are researcher on Economic Research Group - DKM Bank Indonesia. The views on this paper 


\section{PENDAHULUAN}

Peran sektor industri pengolahan dalam perekonomian Indonesia strategis paling tidak karena empat alasan. Pertama, sektor ini merupakan sektor yang berkontribusi terbesar dalam pembentukan Produk Domestik Bruto. Pangsa sektor ini dalam PDB 2011 mencapai sekitar $24,3 \%$. Kedua, sektor ini merupakan salah satu sektor yang memiliki penyerapan tenaga kerja yang cukup besar, setelah sektor pertanian dan sektor perdagangan, hotel dan restoran, serta sektor jasa-jasa. Ketiga, sektor ini merupakan penyumbang utama dalam struktur ekspor nonmigas. Sekitar 38\% dari total nilai ekspor atau sekitar $46 \%$ dari total ekspor nonmigas pada 2011 berasal dari sektor industri pengolahan. Keempat, sektor industri pengolahan memiliki backward lingkage (derajat kepekaan) dan forward linkage (daya penyebaran) yang tinggi dengan sektor lainnya. Hubungan sektor ini dengan sektor-sektor lainnya, baik ke depan maupun ke belakang, berada di atas rata-rata sektor secara keseluruhan.

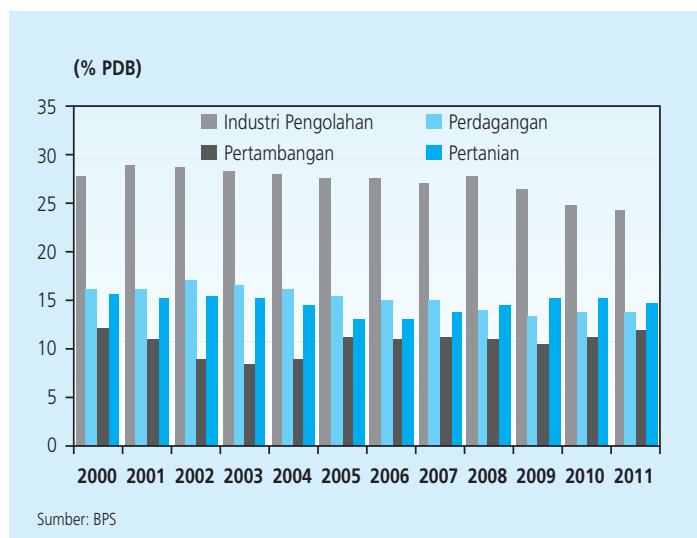

Grafik 1.

Pangsa Sektor Industri Pengolahan dalam PDB
(\%)

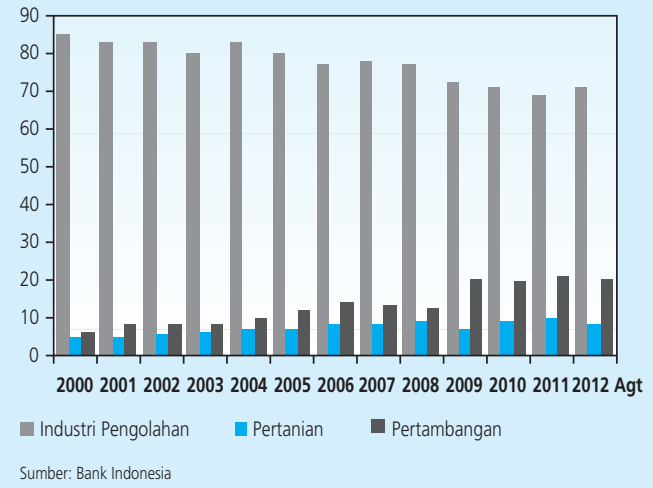

Grafik 2. Struktur Ekspor Nonmigas

\begin{tabular}{|c|c|c|c|c|c|c|}
\hline \multicolumn{7}{|c|}{$\begin{array}{c}\text { Tabel } 1 \\
\text { Pangsa Tenaga Kerja Sektoral }\end{array}$} \\
\hline Sektor & 2006 & 2007 & 2008 & 2009 & 2010 & 2011 \\
\hline Pertanian & 40,14 & 41,21 & 41,33 & 41,61 & 41,49 & 39,33 \\
\hline Perdagangan & 19,22 & 20,55 & 21,22 & 21,95 & 22,49 & 23,40 \\
\hline Industri & 11,89 & 12,37 & 12,55 & 12,84 & 13,82 & 14,54 \\
\hline
\end{tabular}


Pertumbuhan sektor industri pengolahan pada periode prakrisis keuangan 1998 relatif tinggi, yaitu mencapai sekitar 9,2\% (yoy) pada periode 1991-1998. Namun, rata-rata pertumbuhan tersebut menurun paska krisis 1998, yaitu hanya mencapai sekitar 4,6\% (yoy) pada 2001-2011. Bahkan, sejak 2004 pertumbuhannya cenderung melambat dan mulai 2010 dan 2011 mengalami peningkatan. Hal ini menyebabkan kontribusi sektor industri pengolahan terhadap pertumbuhan ekonomi cenderung menurun pada 2004-2009.

(\%)

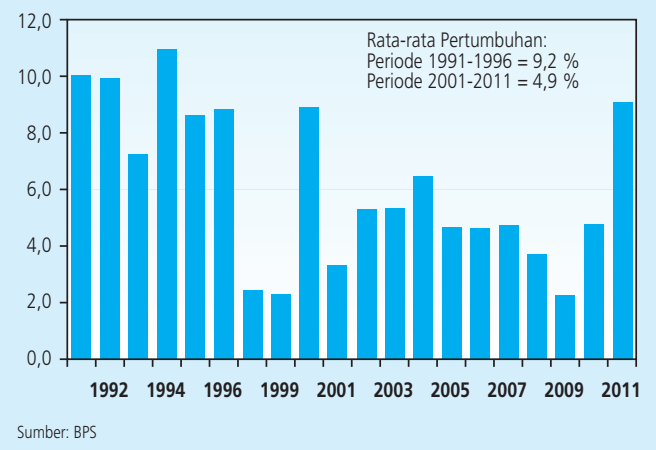

Grafik 3. Pertumbuhan Sektor Industri Pengolahan

Mencermati pentingnya peran sektor industri pengolahan tersebut, analisis terhadap perkembangan produktivitas industri manufaktur Indonesia dipandang perlu, terutama untuk melihat kesinambungan pertumbuhan output di sektor ini. Yang dimaksudkan dengan produktivitas di sini adalah Total Factor Productivity (TFP), meliputi produktivitas keseluruhan faktor produksi, tanpa membedakan faktor produksi secara parsial sebagaimana analisis pada umumnya.

Tujuan penelitian ini pertama adalah menghitung Total Factor Productivity (TFP) perusahaan manufaktur besar dan sedang Indonesia; kedua, mengidentifikasi sumber-sumber pendorong produktivitas sektor industri manufaktur; dan ketiga, menganalisis subsektor industri pengolahan berdasarkan tingkat technical change dan efficiency change. Dengan mengetahui gambaran produktivitas subsektor industri pengolahan dan komponen pembentuknya dapat diidentifikasi potensi dan risiko kinerja sektor industri kedepan serta kebijakan pengembangan yang dibutuhkan.

Bagian kedua dari paper ini akan mengulas teori, bagian ketiga mengulas data dan metodologi yang digunakan, sementara bagian keempat mengulas hasil dan analisis. Kesimpulan akan disajikan pada bagian kelima dan menjadi bagian penutup. 


\section{TEORI}

\subsection{Konsep Produktivitas dan Efisiensi}

Kinerja ekonomi suatu perusahaan dicerminkan dari tingkat efisiensi dan produktivitas, yaitu rasio antara output terhadap input. Semakin besar rasio output terhadap input mengindikasikan semakin tinggi kinerja perusahaan tersebut. Jika dalam proses produksi melibatkan input lebih dari satu, diperlukan metode untuk mengagregatkan input ke dalam suatu indeks agar rasio produktivitas dapat dihitung. Hal yang sama juga perlu dilakukan jika perusahaan menghasilkan multiple output. Pengukuran kinerja ini merupakan pengukuran relatif, dimana kinerja saat ini dibandingkan periode sebelumnya atau dibandingkan kompetitor lainnya.

Terdapat beberapa istilah dalam lingkup produktivitas dan efisiensi yang perlu diperjelas berikut ini; pertama adalah produktivitas. Produktivitas merupakan Rasio antara output yang dihasilkan terhadap input yang digunakan. Produktivitas ini tercermin dalam slope pada suatu titik (kasus 1 output (y) dan 1 input (x)). Seperti terlihat di Grafik 5. perusahaan B memiliki produktivitas lebih tinggi dibandingkan perusahaan $\mathrm{A}$.

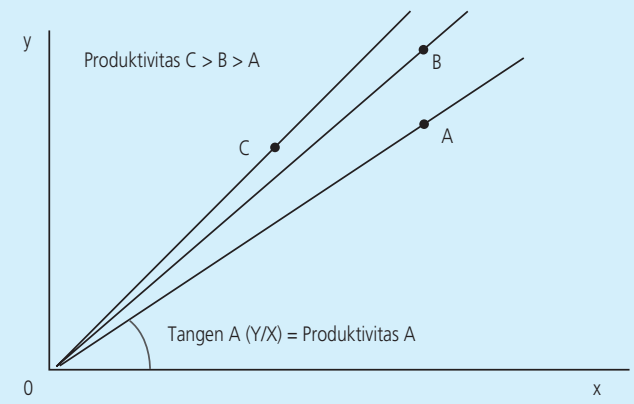

Grafik 4. Ilustrasi Produktivitas

Kedua adalah kurva produksi (production frontier) OF' di Grafik 5 menunjukkan jumlah output maksimum yang dapat dihasilkan di setiap level input atau dengan kata lain kurva produksi ini mencerminkan tingkat penggunaan teknologi di perusahaan tersebut.

Ketiga adalah terminologi efisiensi yang merupakan perbandingan jumlah output suatu perusahaan terhadap output maksimum yang dapat dihasilkan perusahaan sejenisnya di level input yang sama, atau sebaliknya. Perusahaan disebut efisien jika perusahaan tersebut beroperasi tepat di garis kurva produksi (frontier), yaitu di titik B dan C. Sebaliknya, disebut tidak efisien jika perusahaan beroperasi di bawah frontier-nya, yaitu di titik A. Pada titik A perusahaan masih dapat meningkatkan efisiensinya ke titik B tanpa menambah penggunaan input. Pada Grafik 5. terlihat efisiensi perusahaan $A$ sebesar $\mathrm{AA}^{\prime} / \mathrm{BA}^{\prime}$. 


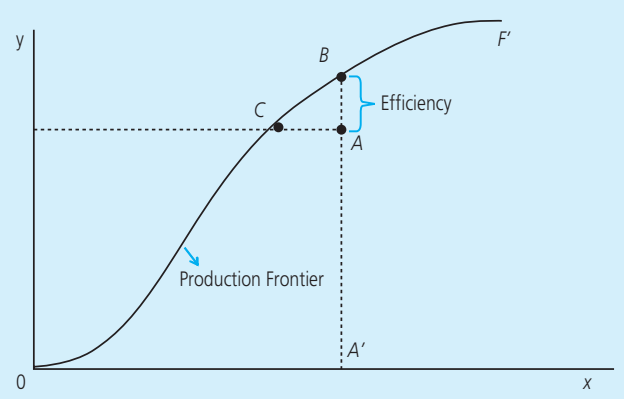

Grafik 5. Ilustrasi Efficiency

Untuk memahami perbedaan antara efisiensi dan produktivitas dapat menggunakan ilustrasi Grafik 6. Seperti yang telah dijelaskan sebelumnya bahwa ukuran produktivitas dapat dilihat dari slope garis lurus dari sumbu nol. Berdasarkan Grafik 6, perusahaan A dan B memiliki produktivitas yang sama, namun nilai efisiensi perusahaan A lebih rendah dibandingkan perusahaan B. Sementara itu, perusahaan B dan C memiliki efisiensi yang sama, namun nilai produktivitas $C$ lebih besar dibandingkan perusahaan B. Dengan demikian, perusahaan yang memiliki produktivitas yang sama belum tentu memiliki efisiensi yang sama, serta perusahaan yang memiliki efisiensi yang sama belum tentu memiliki produktivitas yang sama.

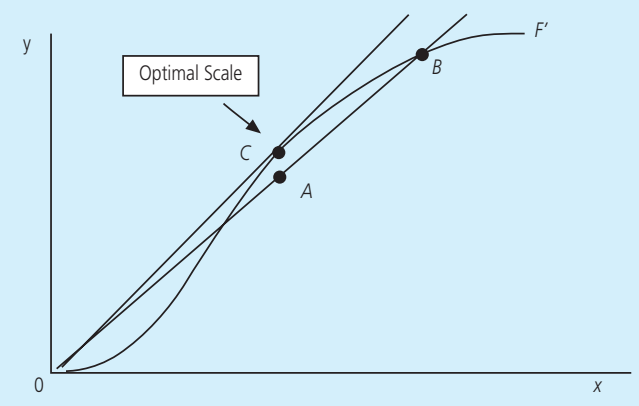

Grafik 6.

llustrasi Perbandingan Efisiensi dan Produktivitas

Allocative efficiency merupakan perpaduan komposisi input yang menghasilkan output dengan biaya paling minimum atau pendapatan paling maksimal. Pengukuran Allocative Efficiency hanya dapat dilakukan ketika nilai biaya input-input tersebut diketahui. Terminologi berikutnya adalah technical change diukur dari pergeseran production frontier katakan dari satu periode ke periode yang lain. Grafik 7. menunjukkan technical change bergeser dari FO' ke F1' 


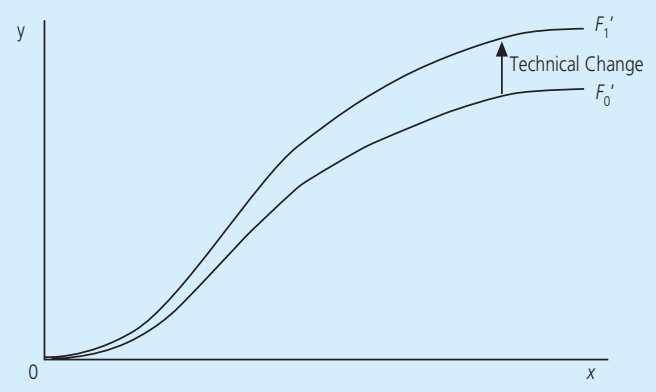

Grafik 7. Ilustrasi Technical Change

Economic of scale juga merupakan terminologi yang sering digunakan. Pengukuran ini hanya dapat dilakukan ketika asumsi Constant Return to Scale dihilangkan (menjadi Variabel Return to Scale). Nilai skala ekonomis (economic scale) diperoleh dengan membandingkan kondisi CRS dan VRS. Grafik 8 mengilustrasikan skala ekonomis (area abu-abu) terdapat di antara kurva OB (Production Frontier - CRS) dan kurva OF' (Production Frontier - VRS). Sedangkan, optimal scale merupakan titik dimana perusahaan yang berada di frontier VRS (kurva OF') dan memiliki produktivitas tertinggi dibandingkan perusahaan-perusahaan lainnya yang juga berada di kurva OF'. Dengan demikian perusahaan C berada di titik optimal scale.

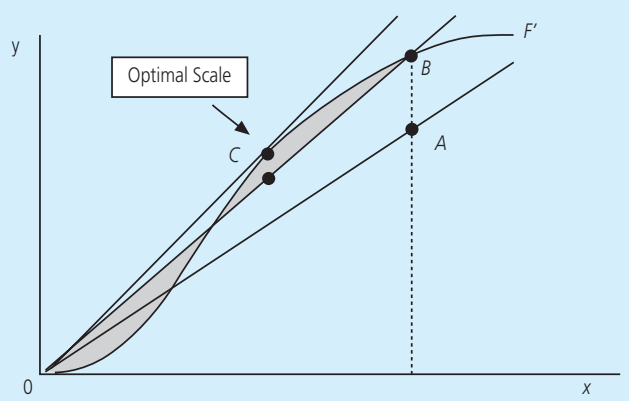

Grafik 8. Ilustrasi Skala Ekonomis

Terminologi terkahir yang perlu diperjelas adalah Total Factor Productivity (TFP) yang menjadi fokus dalam paper ini. TFP merupakan produktivitas yang mempertimbangkan seluruh faktor produksi², dan dapat di dekomposisi menjadi efficiency, technical change, dan economic

2 Termasuk memperhitungkan semua output dalam kasus produksi multiple-output. 
scale. Dengan demikian, konsep TFP ini berbeda dengan metode umum yang menghitung TFP dari residual (teknologi) dalam suatu fungsi produksi dengan input kapital dan tenaga kerja.

\subsection{Pengukuran Produktivitas dan Efisiensi}

Kita memiliki tiga pilihan dalam mengukur efisiensi; input oriented, output oriented, dan distance function. Pada pilihan pertama, kita menetapkan suatu target output berusaha memilih input seminimal mungkin. Dengan demikian, variabel yang sangat diperhatikan adalah penggunaan input. Pada sisi lain, pendekatan output oriented menargetkan sejumlah input tertentu kemudian berusaha memaksimalkan output. Kedua pendekatan ini diilustrasikan berikut.

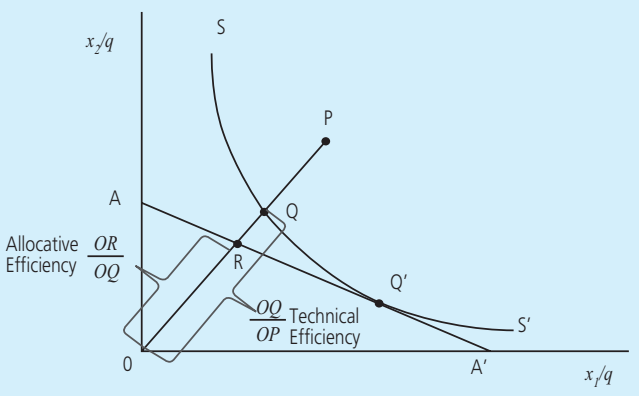

Grafik 9. Input Oriented

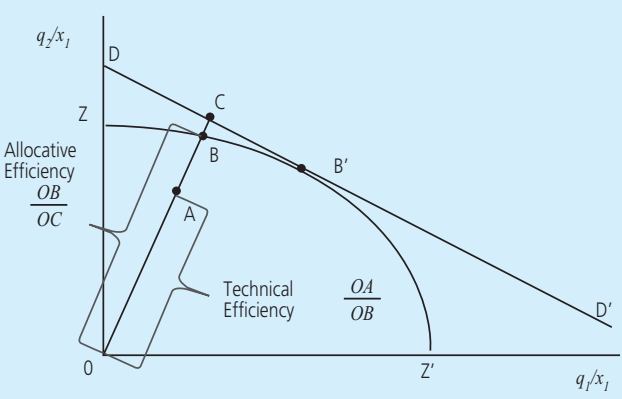

Grafik 10. Output Oriented

Pendekatan ketiga, distance function, lebih sering dijumpai dalam literatur akademik. Sebelum sampai pada distance function, terlebih dahulu akan dijelaskan tentang production technology, yang menggambarkan tentang multiple-output production technology. Representasi technology setini dapat dilihat dalam Coelli (2005) mengikuti Fare dan Primont (1995),

Katakan S merupakan technology set, sementara notasi x dan q masing-masing mewakili Nx1 vektor input dan $M x 1$ vektor output. Vektor tersebut merupakan bilangan riil yang bukan negatif. Technology set di bawah ini terdiri dari seluruh vektor input dan output $(\mathrm{x}, \mathrm{q})$ dimana $\mathrm{x}$ menghasilkan $\mathrm{q}$.

$$
\mathrm{S}=\{(\mathrm{x}, \mathrm{q}): \mathrm{x} \text { dapat menghasilkan } \mathrm{q}\}
$$

Production technology dapat direpresentasikan dengan output dan input sets sbb.:

a) Output Sets, $\mathrm{P}(\mathrm{x})$, merupakan sekumpulan output vector, $\mathrm{q}$, yang dapat dihasilkan dengan menggunakan input vector, $\mathrm{x}$. Output set menjadi dasar untuk membentuk production possibility curve dengan dua dimensi vektor output. 


$$
P(x)=\{q: x \text { dapat menghasilkan } q\}=\{q:(x, q) \in S\}
$$

b) Input Sets, L(q), adalah sekumpulan input vector, $x$, yang dapat menghasilkan output vector tertentu, q.

$$
\mathrm{L}(\mathrm{q})=\{\mathrm{x}: \mathrm{x} \text { dapat menghasilkan } \mathrm{q}\}=\{\mathrm{x}:(\mathrm{x}, \mathrm{q}) \in \mathrm{S}\}
$$

Multi-output technology dapat dicontohkan dengan menggunakan pendekatan satu input $\left(x_{1}\right)$ dan dua output $\left(q_{1}\right.$ dan $\left.q_{2}\right)$. Kita dapat merumuskan input sebagai fungsi dari dua output tersebut:

$$
x_{1}=g\left(q_{1}, q_{2}\right)
$$

Kombinasi 2 output yang dapat dihasilkan dari sejumlah input tertentu dapat digambarkan dalam suatu production possibility curve (PPC). Jika kurva PPC bersinggungan dengan kurva isorevenue, maka akan diperoleh kombinasi output yang menghasilkan profit maksimum. Titik optimal yang menghasilkan pendapatan maksimal berada di titik $A$, di saat kemiringan isorevenue (-p1/p2) sama dengan kemiringan kurva PPC.

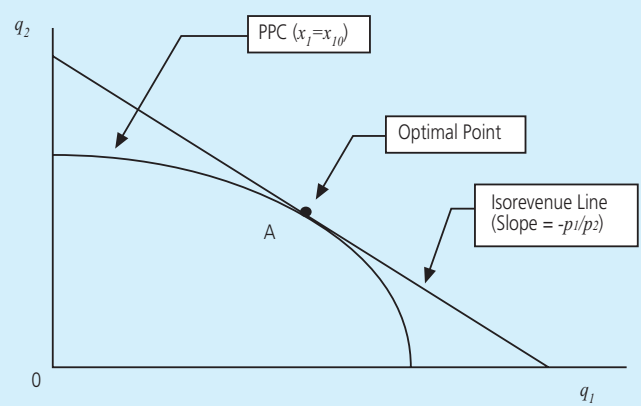

Grafik 11. Production Possibility Curve dan Maksimisasi Pendapatan

Dalam kasus multiple output, technical change dapat mengubah produksi satu output relatif terhadap output lainnya dalam dua jenis. Dari grafik berikut, kita dapat membedakan antara neutral dan non-neutral technical change. 

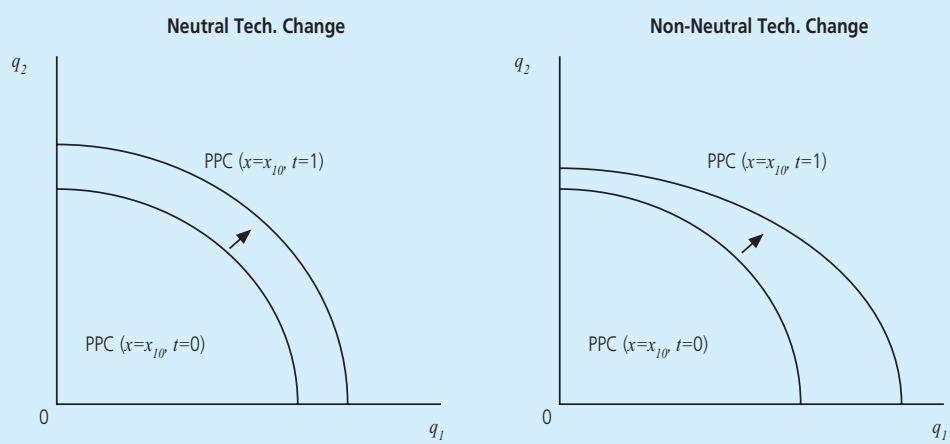

Grafik 12. Technical Change Bias dan Production Possibility Curve

Konsep distance function dapat diaplikasikan baik pada output dan input, distance function dari perusahaan yang beroperasi di titik A pada Grafik 13 dan 14 adalah rasio dari OA OB. Distance function yang bernilai 1 (satu) menunjukkan bahwa perusahaan sudah beroperasi di PPC atau isoquant.

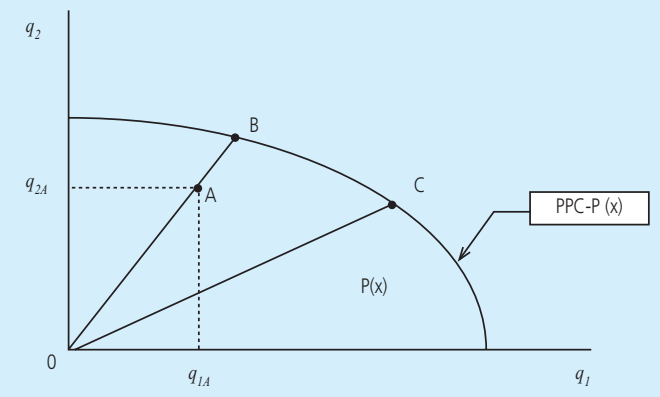

Grafik 13. Output Distance Function

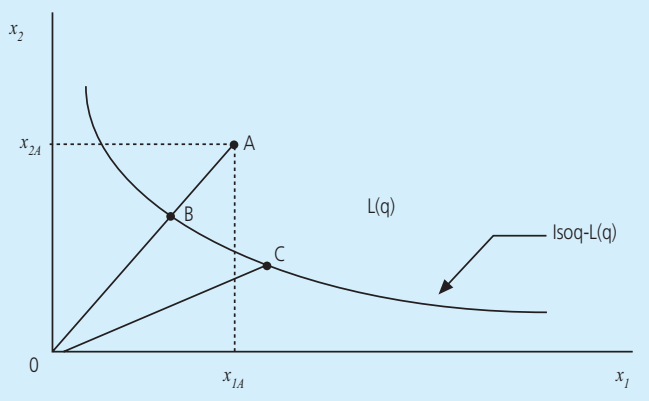

Grafik 14. Input Distance Function

\subsection{Malmquist Productivity Index}

Pengukuran produktivitas dalam paper ini mengacu pada total factor productivity (TFP) dari seluruh faktor yang digunakan, dan bukan produktivitas yang bersifat parsial, seperti labor productivity atau capital productivity. Pengukuran parsial dapat menimbulkan misleading ketika menilai kinerja suatu perusahaan atau industri. Untuk mengukur TFP suatu perusahaan yang memproduksi beberapa produk dan beberapa input, kita dapat menggunakan 
ukuran profitabilitas perusahaan, yaitu rasio antara pendapatan dibagi dengan biaya input perusahaan.

Dalam kasus perbandingan 2 perusahaan, TFP diukur dengan membandingkan profit kedua perusahaan tersebut. Setelah memasukkan unsur harga dari masing-masing output dan input, maka pengukuran produktivitas secara sederhana dapat dilakukan dengan persamaan di bawah ini. Dalam hal ini, tingkat produktivitas kedua perusahaan diukur dengan membandingkan tingkat output riil dan tingkat input riil.

$$
\frac{\pi_{2}^{*}}{\pi_{1}^{*}}=\frac{q_{2} / x_{2}}{q_{1} / x_{1}}
$$

Untuk membahas pengukuran perubahan produktivitas perusahaan antara 2 periode, maka akan melibatkan 2 production technology set, yaitu $\mathrm{S}^{\mathrm{s}}$ dan $\mathrm{S}^{\mathrm{t}}$, masing-masing untuk periode $s$ dan $t$. Setiap technology set melibatkan vektor output $\mathrm{q}_{\mathrm{s}}$ dan $\mathrm{q}_{\mathrm{t}^{\prime}}$ serta vektor input $\mathrm{x}_{\mathrm{s}}$ dan $\mathrm{x}_{\mathrm{t}}$. Pendekatan yang sering digunakan untuk perbandingan ini adalah Malmquist Productivity Index (MPI).

MPI pertama kali diperkenalkan oleh menggunakan Caves, Christensen dan Diewert (1982); sebuah pendekatan fungsi jarak untuk menggambarkan teknologi dalam mendefinisikan indeks input, output, dan produktivitas. Untuk output yang diproduksi pada periode $s$ dan $t$, maka terdapat teknologi yang menghasilkan output maksimum dengan menggunakan input $\mathrm{x}_{\mathrm{s}}$ dan $\mathrm{x}_{\mathrm{t}}$. Sebagai contoh, jika suatu perusahaan pada periode $\mathrm{s}$ berproduksi sebesar $80 \%$ dari kapasitas maksimumnya dengan vektor input $\mathrm{x}_{\mathrm{s}^{\prime}}$ dan pada periode $t$ dapat menghasilkan output $30 \%$ di atas kapasitas maksimumnya dengan menggunakan input vector $\mathrm{x}_{\mathrm{t}^{\prime}}$ maka perubahan produktivitas dari periode $s$ ke $t$ adalah 1,30/0,80 =1,625.

Perhitungan MPI dengan acuan teknologi pada periode $s$ adalah:

$$
m_{0}^{s}\left(q_{s}, q_{t}, x_{s}, x_{t}\right)=\frac{d_{o}^{s}\left(q_{t}, x_{t}\right)}{d_{o}^{s}\left(q_{s}, x_{s}\right)}
$$

Jika diasumsikan bahwa perusahaan mencapai technically efficiency (selanjutnya disebut efficiensi) di kedua periode, maka $d_{o}{ }^{s}\left(q_{s^{\prime}} x_{s}\right)=1$, sehingga :

$$
m_{0}^{s}\left(q_{s}, q_{t}, x_{s}, x_{t}\right)=d_{o}^{s}\left(q_{t}, x_{t}\right)
$$

Jika MPI dengan acuan teknologi di periode $t$ maka menjadi persamaan di bawah ini.

$$
m_{0}^{t}\left(q_{s}, q_{t}, x_{s}, x_{t}\right)=\frac{d_{o}^{t}\left(q_{t}, x_{t}\right)}{d_{o}^{t}\left(q_{s}, x_{s}\right)}
$$


Berdasarkan pengukuran MPI di periode $s$ dan $t$ di atas dapat dihitung Malmquist TFP Index (MTFPI) yang merupakan rata-rata geometrik dari kedua index di periode $s$ dan $t$ sbb:

$$
m_{0}\left(q_{s}, q_{t}, x_{s}, x_{t}\right)=\left[m_{0}^{s}\left(q_{s}, q_{t}, x_{s}, x_{t}\right) \times m_{0}^{t}\left(q_{s}, q_{t}, x_{s}, x_{t}\right)\right]^{0.5}
$$

MTFPI dapat dipecah menjadi 2 komponen, efficiency change dan technical change. Dengan menggunakan output orientated MFTPI, maka persamaan MTFPI di atas dapat dinyatakan sebagai:

$$
\operatorname{MTFPI}=\left[\frac{d_{o}^{s}\left(x_{t}, q_{t}\right)}{d_{o}^{t}\left(x_{s}, q_{s}\right)} \times \frac{d_{o}^{t}\left(x_{t}, q_{t}\right)}{d_{o}^{t}\left(x_{s}, q_{s}\right)}\right]^{0.5}
$$

Dalam kenyataannya, perusahaan sering beroperasi dalam kondisi yang tidak efisien sehingga $d_{o}{ }^{s}\left(q_{s^{\prime}} x_{s}\right) \leq 1$ dan $d_{o}{ }^{t}\left(q_{t^{\prime}} x_{t}\right) \leq 1$. Jika inefisiensi terjadi, maka MTFPI dapat dinyatakan sebagai:

$$
\begin{gathered}
m_{0}\left(q_{s}, q_{t}, x_{s}, x_{t}\right)=\frac{d_{o}^{t}\left(x_{t}, q_{t}\right)}{d_{o}^{s}\left(x_{s}, q_{s}\right)}\left[\frac{d_{o}^{s}\left(x_{t}, q_{t}\right)}{d_{o}^{t}\left(x_{t}, q_{t}\right)} \times \frac{d_{o}^{s}\left(x_{s}, q_{s}\right)}{d_{o}^{t}\left(x_{s}, q_{s}\right)}\right]^{0.5} \\
\text { Efficiency Change }=\frac{d_{o}^{t}\left(x_{t}, q_{t}\right)}{d_{o}^{s}\left(x_{s}, q_{s}\right)} \\
\text { Technical Change }=\left[\frac{d_{o}^{s}\left(x_{t}, q_{t}\right)}{d_{o}^{t}\left(x_{t}, q_{t}\right)} \times \frac{d_{o}^{s}\left(x_{s}, q_{s}\right)}{d_{o}^{t}\left(x_{s}, q_{s}\right)}\right]^{0.5}
\end{gathered}
$$

Persamaan MTFPI terakhir di atas dapat dipecah menjadi 2 komponen. Komponen pertama mengukur perubahan efisiensi antara periode $s$ dan $t$, sedangkan komponen lainnya yang berada di dalam tanda kurung berpangkat mengukur perubahan teknologi antara 2 periode.

Pengukuran perubahan produktivitas di atas dapat dinyatakan secara grafis di bawah ini. Diasumsikan perusahaan memiliki sifat produksi constant returns to scale dengan satu input dan satu output. Di periodes, perusahaan berproduksi di titik D dan bergerak ke titik E di periode $t$, di mana kedua titik adalah inefisien. Dari grafik di bawah ini, efficiency dan technical change, masing-masing diukur dari :

$$
\text { EfficiencyChange }=\frac{q_{t} / q_{c}}{q_{s} / q_{a}} \text { dan TechnicalChange }=\left[\frac{q_{t} / q_{b}}{q_{t} / q_{c}} \times \frac{q_{s} / q_{a}}{q_{s} / q_{b}}\right]^{0,5}
$$




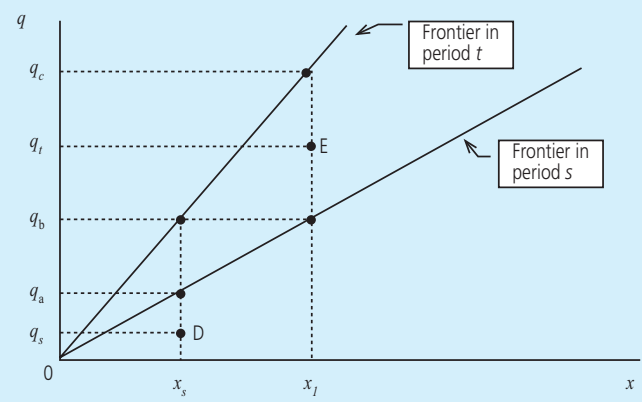

Grafik 15. Malmquist Productivity Index

Mengingat perhitungan MTFPI dibangun berdasarkan asumsi CRS, maka hanya ada 2 sumber pertumbuhan produktivitas, yaitu efficiency change dan technical change. Padahal, jika menggunakan variable returns to scale, selain kedua sumber pertumbuhan produktivitas tersebut, terdapat pula sumber pertumbuhan produktivitas yang berasal dari perbaikan skala operasi atau skala efisiensi. Hal ini merupakan kelemahan dari MTFPI yang selanjutnya disempurnakan oleh Grifell-Tatje dan Lovell (1999) melalui a generalised Malmquist Productivity Index dengan memasukkan unsur produktivitas yang bersumber dari perbaikan skala efisiensi.

\subsection{Data Envelopment Analysis}

Data Envelopment Analysis (DEA) merupakan pendekatan yang berorientasi data, dan untuk mengevaluasi kinerja dari satu set entitas yang disebut DMU (Decision Making Units) yang mengkonversi multiple input ke multiple output. Estimasi production frontier dalam sejumlah DMU yang homogen, menggunakan pendekatan non-parametric mathematical programming.

Pencetus pertama estimasi frontier dengan pendekatan piecewise-linear convex hull adalah Farrell (1957). Perkembangan selanjutnya oleh Boles (1966) dan Afriat (1972) menggunakan metode mathematical programming dalam menyelesaikan estimasi frontier tersebut. Namun, istilah DEA mulai menarik perhatian saat Charnes, Cooper, dan Rhodes (1978) memperkenalkannya melalui model yang bersifat orientasi input dan menggunakan asumsi Constant Return to Scale (CRS). Banker, Charnes, dan Cooper (1984) melakukan perkembangan model dengan menggunakan asumsi Variable Return to Scale (VRS).

Diasumsikan terdapat $N$ input dan $M$ output untuk tiap / perusahaan. Untuk tiap perusahaan ke-I direpresentasikan dengan vektor kolom $x_{i}$ dan $q_{i}$. Matriks input $N x I, X$, dan matriks output $M x I, Q$, merepresentasikan data untuk semua perusahaan. Model DEA menggunakan ukuran 
rasio; untuk tiap perusahaan diukur rasio agregasi output dengan agregasi input. Proses agregasi menggunakan bobot dimana bobot optimal diselesaikan dengan pendekatan mathematical programming. Berikut model DEA dalam bentuk Fractional Program (FP):

$$
\begin{gathered}
\max _{u, v}\left(u^{\prime} q_{i} / v^{\prime} x_{i}\right), \\
\text { st } \quad u^{\prime} q_{i} / v^{\prime} x_{j} \leq 1 \\
u, v \geq 0 \\
j=1,2, \ldots, I
\end{gathered}
$$

Bobot optimal $u$ dan $v$ dalam FP di atas diperoleh dari maksimisasi nilai efisiensi dengan batasan nilai efisiensi kurang dari atau sama dengan 1. Permasalahan yang muncul dalam FP diatas adalah terdapatnya solusi yang tidak terbatas. Untuk itu, model dalam bentuk FP tersebut dikonversi ke dalam bentuk Linear Programming (LP) sebagaimana berikut ini:

\section{$\max _{\mu, v}\left(\mu^{\prime} q_{i}\right)$}

$$
\begin{array}{ll}
\text { st } \quad & v^{\prime} x_{i}=0 \\
& \mu^{\prime} q_{j}-v^{\prime} x_{j} \leq 0 \\
& \mu, v \geq 0 \\
& j=1,2, \ldots, I
\end{array}
$$

Notasi bobot untuk FP dan LP dibedakan dengan tujuan hanya untuk membedakan bentuk mathematical programming-nya. Bentuk model DEA pada LP sudah dapat diselesaikan, namun mempertimbangkan akan semakin banyaknya jumlah batasan seiring dengan meningkatkan jumlah perusahaan (semakin kompleks), maka perlu dilakukan perubahan bentuk LP menjadi Dual Programming (DP). Pada DP, jumlah batasan tidak akan bertambah seiring meningkatnya perusahaan melainkan hanya menambah variabel dalam batasan tersebut.

$$
\min _{\theta, \lambda} \theta
$$

$$
\begin{array}{ll}
\text { st } & -q_{i}+Q \lambda \geq 0, \\
& \theta x_{i}-X \lambda \geq 0, \\
& \lambda \geq 0
\end{array}
$$


Sedangkan untuk persamaan dual-programming dengan orientasi output adalah sebagai berikut (Penjelasan selanjutnya akan menggunakan orientasi output):

$$
\begin{array}{ll} 
& \max _{\phi, \lambda} \phi, \\
\text { st } \quad-\phi q_{i}+Q \lambda \geq 0, \\
\\
x_{i}-X \lambda \geq 0, \\
\lambda \geq 0,
\end{array}
$$

Pada DEA Constant Return to Scale (CRS) mengasumsikan semua DMU bekerja pada skala ekonomis yang paling optimal. Namun, adanya kompetisi tidak sempurna, keterbatasan pada keuangan, yang membuat DMU tidak dapat bekerja pada skala ekonomis optimal, untuk itu, dikembangkan model DEA dengan asumsi Variable Return to Scale (VRS). Model VRS tidak jauh berbeda dengan model CRS, yaitu hanya penambahan convexity constraint $\left(11^{\prime} \lambda=1\right)$. Berikut model DEA yang menggunakan asumsi VRS:

$$
\begin{array}{ll} 
& \max _{\phi, \lambda} \phi, \\
\text { st } \quad-\phi q_{i}+Q \lambda \geq 0, \\
& x_{i}-X \lambda \geq 0, \\
& I^{\prime} \lambda=1 \\
& \lambda \geq 0,
\end{array}
$$

Skala ekonomi yang dihasilkan pada model tersebut tidak mengindikasikan apakah perusahaan increasing atau decreasing returns to scale. Untuk itu dilakukan non-increasing returns to scale (NIRS) pada model DEA. Jika TE (Technical Efficiency atau biasa disebut hanya efficiency) NIRS tidak sama dengan TE VRS maka terindikasi Increasing Return to Scale (IRS). Sedangkan jika TE NIRS sama dengan TE VRS maka terindikasi Decreasing Return to Scale (DRS).

$$
\begin{array}{ll} 
& \max _{\phi, \lambda} \phi, \\
\text { st } \quad-\phi q_{i}+Q \lambda \geq 0, \\
x_{i}-X \lambda \geq 0, \\
I 1^{\prime} \lambda \leq 1
\end{array}
$$$$
\lambda \geq \mathbf{0} \text {, }
$$ 


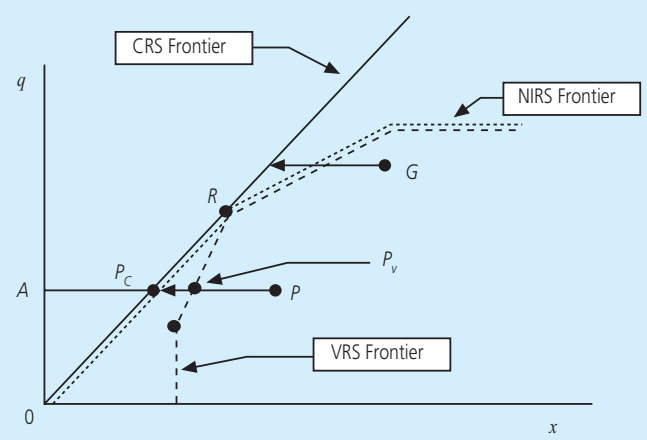

Grafik 16. Ilustrasi Non-Increasing Returns to Scale

Hasil estimasi dual programming tidak selalu menghasilkan titik efisiensi yang optimal. Untuk memastikan hasil estimasi yang diperoleh adalah efisiensi optimal, maka kita dapat menggunakan model dengan variabel slack berikut:

$$
\begin{array}{cl}
\max _{\lambda, o S, I S} & -\left(M 1^{\prime} O S+N 1^{\prime} I S\right), \\
\text { st } & -\phi q_{i}+Q \lambda-O S=0, \\
& x_{i}-X \lambda-I S=0, \\
& \lambda \geq 0, O S \geq 0, I S \geq 0,
\end{array}
$$

$\phi$ merupakan parameter yang nilainya diperoleh dari hasil tahap pertama; OS merupakan vector of output slacks dengan dimensi $M \times 1$; IS adalah vector of input slacks dengan ukuran Nx1; sementara M1 dan N1 merupakan vektor kolom satu (vector of ones) masing-masing dengan ukuran $M \times 1$ dan $N \times 1$.

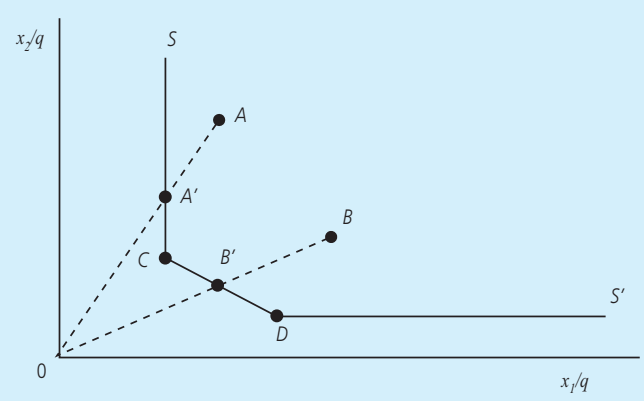

Grafik 17. Ilustrasi Slack (Input Oriented) 
Estimasi Total Factor Productivity (TFP) dengan pendekatan DEA mengunakan pendekatan index. Ilustrasi TFP indeks seperti berikut: Jika suatu perusahaan dapat menghasilkan output yg sama pada periode $t$ dan $t+1$, namun menggunakan input yg berbeda, yaitu hanya $75 \%$ dari input periode $t$, maka TFP index akan meningkat sebesar 1/0.75. Atau, jika perusahaan menggunakan input yang sama di periode $t$ dan $t+1$, namun menghasilkan output yang berbeda yaitu output periode $t+1$ meningkat sebesar $30 \%$ dari output periode $t$, maka TFP index sebesar 1,3.

Selain MTFI yang telah dijelaskan panjang lebar sebelumnya, juga terdapat dua cara lain dalam perhitungan indeks TFP, yaitu Hicks-Moorsteen TFP (HM TFP) Index, dan TFP Index berdasarkan Profitability Ratio. Ilustrasi perhitungan indeks di atas menggunakan HM TFP index dengan formula sederhana berikut:

$$
\text { HMTFP Index }=\frac{\text { Growth in Output }}{\text { Growth in Intput }}=\frac{\text { Output Quantity Index }}{\text { Input Quantity Index }}
$$

Namun, terdapat kekurangan dari HM TFP index yaitu ketidakmampuan menjelaskan sumber pertumbuhan produktivitas tersebut (technical change, efficiency change).

Pada sisi lain, metode perhitungan Profitability Ratio mengukur indeks TFP dengan menggunakan pendapatan dan biaya (setelah disesuaikan dengan perubahan harga antar periode $s$ dan $t$ ). Seperti HM TFP index, kekurangan dari TFP Profitability Ratio adalah tidak memperhitungan price effects. Dengan alasan ini, maka index yang akan digunakan dalam penelitian ini adalah Malmquist TFP Index.

\subsection{Penelitian tentang TFP Sektor Industri Pengolahan di Indonesia}

Beberapa peneliti telah meneliti tentang produktivitas dan efisiensi perusahaan di Indonesia. Secara garis besar penelitian di bidang ini dapat digolongkan ke dalam 2 kelompok, yaitu yang menggunakan pendekatan Data Envelopment Analysis (DEA) dan pendekatan Stochastic Frontier Approach (SFA). Pendekatan yang pertama bersifat non-parametrik, sedangkan yang kedua adalah parametrik.

Di kelompok SFA, Ikhsan (2007) meneliti pertumbuhan TFP dan perubahan efisiensi teknikal di industri pengolahan Indonesia pada periode 1988-2000. Dengan menggunakan data Statistik Industri Besar dan Sedang (SIBS), penelitian ini menyimpulkan bahwa rata-rata pertumbuhan TFP periode tersebut sebesar 1,55\%. Kontributor pertumbuhan TFP terutama berasal dari technical progress sekitar 1,89\%, sedangkan kontribusi dari skala ekonomis dan technical efficiency (kadang hanya disebut efficiency) masing-masing -0,13\% dan -0,21\%. Di sisi perubahan technical efficiency terlihat adanya proses learning by doing dalam pengadopsian teknologi karena perusahaan tidak beroperasi di kapasitas produksi maksimumnya. 
Metodologi yang dilakukan dalam penelitian Ikhsan tersebut kemudian diadopsi oleh Bappenas (2010) dengan menggunakan data SIBS periode 2000-2007. Rata-rata pertumbuhan produktivitas pada periode penelitian ini sekitar 0,22\%. Pertumbuhan produktivitas ini lebih rendah dibandingkan periode sebelum krisis $1998^{3}$. Setelah sempat turun di periode 20002004, yang diduga terkait dengan proses konsolidasi kebijakan perekonomian pascakrisis 1998, produktivitas industri meningkat kembali pada 2004-2007.

Sebagai kontributor utama peningkatan produktivitas dalam penelitian Bappenas adalah pertumbuhan efisiensi teknikal. Sementara itu, pertumbuhan teknologi dan skala ekonomi berkontribusi negatif terhadap TFP, masing-masing -0,17\% dan -0,45\%. Di level disagregasi pada 2 digit ISIC, sektor kimia mencatat pertumbuhan pertumbuhan TFP tertinggi mencapai ratarata $0,21 \%$ per tahun, yang diikuti oleh sektor mineral nonmetal $(0,14 \%)$ dan sektor makanan dan minuman (0,09\%). Sementara itu, pertumbuhan produktivitas terendah dialami oleh sektor industri kayu (-1,18\%), sektor manufaktur lain (-0,31\%), dan sektor tekstil (-0,08\%).

Prabowo dan Cabanda (2011) meneliti produktivitas perusahaan manufaktur Indonesia yang tercatat di Bursa Efek Indonesia periode tahun 2000-2005. Masih dengan metode SFA, Prabowo dan Cabanda menemukan adanya inefisiensi teknis di perusahaan yang menjadi sampel penelitian. Rata-rata technical eficiency perusahaan bernilai 0,7149 yang berarti masih berada di bawah frontiernya.

Sementara itu, Saputra (2011) dan Halim (2010) meneliti produktivitas sektor industri dengan menggunakan metode DEA. Saputra meneliti tingkat technical efficiency perusahaan sektor industri Indonesia. Dengan menggunakan data UNIDO di level 3 digit ISIC, disimpulkan bahwa untuk periode 1990-2001 terdapat 5 subsektor industri yang memiliki efisiensi tertinggi, yaitu: Tembakau; Besi dan Baja; Peralatan Transportasi; Non-Ferrous Metal; dan Kimia. Secara umum, subsektor industri kategori industri dasar menunjukkan efisiensi yang lebih tinggi dibandingkan industri dalam kategori low traditional and high-tech industry. Meskipun demikian, industri yang berada dalam kategori terakhir, dalam 2 tahun terakhir pengamatan cenderung menunjukkan efisiensi yang semakin tinggi.

Halim (2010) secara spesifik meneliti produktivitas marketing yang ditempuh dan profitabilitas perusahaan. Terkait dengan tujuannya, input yang digunakan dalam penelitian ini terbatas pada equity dan marketing expenses. Metode DEA diaplikasikan pada 5 kategori industri perusahaan manufaktur yang tercatat di BEl sepanjang 2001-2007, meliputi: Makanan dan Minuman; Pakaian dan Produk Tekstil; Plastik dan Barang dari Gelas; Otomotif dan produknya; serta Farmasi. Kesimpulan utama dari penelitian ini adalah bahwa di tahun 20052006 produktivitas marketing memiliki nilai yang tertinggi dibandingkan dengan periode lainnya dengan kontributor utama technological efficiency. Sebanyak 44 perusahaan teridentifikasi beroperasi di tingkat yang efisien, dimana berdasarkan kategorinya, sektor otomotif memiliki nilai

3 Yaitu periode 1988-1992 dan 1993-1996. 
produktivitas dan technical efficiency tertinggi. Nilai TFP dari perusahaan yang efisien tersebut memiliki hubungan positif dengan returns on asset yang mencerminkan bahwa semakin tinggi marketing productivity efficiency maka semakin baik kinerja keuangan.

\section{METODOLOGI}

\subsection{Metodologi}

Dalam paper ini, estimasi pertumbuhan TFP serta komponen-komponennya mengacu pada Malmquist Indeks dan aplikasi metode DEA-Dual Programming. Komponen-komponen Total Factor Productivity yang diestimasi meliputi perubahan teknologi, perubahan efisiensi, dan perubahan skala ekonomis, dan untuk tiap perusahaan di tiap subsektor dan di tiap tahunnya.

Model Output Oriented Malmquist DEA dapat didefinisikan sebagai berikut:

$$
\begin{array}{ll} 
& \max _{\phi, \lambda} \phi, \\
\text { st } \quad-\phi q_{i}+Q \lambda \geq 0, \\
\\
x_{i}-X \lambda \geq 0, \\
\lambda \geq 0,
\end{array}
$$

Dimana $\phi$ merupakan peningkatan proporsional output yang dicapai oleh perusahaan ke-i, dengan kondisi input yang konstan; $\lambda$ merupakan bobot untuk masing-masing input atau output; variabel q merupakan nilai output untuk perusahaan ke-i, variabel Q merupakan nilai output untuk perusahaan-perusahaan lainnya. Sementara itu, variabel x merupakan nilai input untuk perusahaan ke-i, variabel $X$ merupakan nilai input untuk masing-masing perusahaan lainnya.

Sedangkan TFP malmquist indeks didefinisikan sebagai berikut:

$$
m_{0}\left(q_{s}, q_{t}, x_{s}, x_{t}\right)=\left[m_{0}^{s}\left(q_{s}, q_{t}, x_{s}, x_{t}\right) \times m_{0}^{t}\left(q_{s}, q_{t}, x_{s}, x_{t}\right)\right]^{0.5}
$$

Selanjutnya, komponen-komponen Total Factor Productivity diperoleh dari breakdown malmquist indeks, sebagai berikut

$$
\text { Total Efficiency Change }=\frac{d_{o}^{t}\left(x_{t}, q_{t}\right)}{d_{o}^{s}\left(x_{s}, q_{s}\right)}
$$

$$
\text { Technical Change }=\left[\frac{d_{o}^{s}\left(x_{t}, q_{t}\right)}{d_{o}^{t}\left(x_{t}, q_{t}\right)} \times \frac{d_{o}^{s}\left(x_{s}, q_{s}\right)}{d_{o}^{t}\left(x_{s}, q_{s}\right)}\right]^{0.5}
$$




$$
\text { Efficiency Change }=\frac{d_{o v}^{t}\left(q_{t}, x_{t}\right)}{d_{o v}^{s}\left(q_{s}, x_{s}\right)}
$$

Economic Scale Change $=\left[\frac{d_{o v}^{t}\left(q_{t}, x_{t}\right) / d_{o c}^{t}\left(q_{t}, x_{t}\right)}{d_{o v}^{t}\left(q_{s}, x_{s}\right) / d_{o c}^{t}\left(q_{s}, x_{s}\right)} \times \frac{d_{o v}^{s}\left(q_{t}, x_{t}\right) / d_{o c}^{s}\left(q_{t}, x_{t}\right)}{d_{o v}^{s}\left(q_{s}, x_{s}\right) / d_{o c}^{s}\left(q_{s}, x_{s}\right)}\right]^{0.5}$

\subsection{Data, Variabel, dan Proksi}

Data utama yang digunakan dalam penelitian ini adalah data Survei Industri Besar dan Sedang (SIBS) yang dikeluarkan oleh Badan Pusat Statistik (BPS). Periode tahun yang digunakan yaitu dari tahun 2000-2009. Masing-masing perusahaan (KIPN) dikelompokkan berdasarkan 3 digit ISIC. Untuk setiap perusahaan, variabel yang digunakan mencakup output, modal, tenaga kerja, bahan baku, dan energi.

Untuk mengetahui output yang dihasilkan oleh suatu perusahaan, kita dapat menggunakan pendekatan hasil produksi atau hasil penjualan. Penelitian ini menggunakan yang proksi yang pertam. Hal ini mempertimbangkan semua sumber daya (modal, tenaga kerja, bahan baku dan energi) menghasilkan sejumlah output baik yang terjual maupun yang tidak terjual dan disimpan sebagai persediaan. Data nilai produksi yang dihasilkan tersebut akan diriilkan dengan menggunakan indeks harga perdagangan besar indonesia berdasarkan sektor industri masing-masing.

Data modal yang digunakan pada penelitian ini adalah nilai taksiran (stok) seluruh barang modal tetap (tanah, gedung, mesin, kendaraan, dan lainnya). Beberapa data modal (stok) yang tidak terisi saat pelaksanaan survei, diperoleh dengan melakukan perkiraan. Data modal pada tahun $\mathrm{t}$ dapat mengestimasi modal tahun lainnya dengan mempertimbangkan nilai investasi (pembelian atau perbaikan), nilai penjualan, serta depresiasi (asumsi 14\%) pada tahun-tahun tersebut. Deflator yang digunakan untuk meriilkan data barang modal ini adalah deflator Pembentukan Modal Tetap Domestik Bruto (PMTB) di PDB sisi penggunaan.

Penggunaan data tenaga kerja yang paling tepat yaitu menggunakan data jumlah jam kerja. Hal ini berkaitan dengan jumlah tenaga kerja yang sama di suatu perusahaan akan menghasilkan output yang berbeda bila jumlah jam kerja berubah (terdapat lembur atau pemberhentian sementara proses produksi). Namun, dengan adanya keterbatasan data maka penelitian ini menggunakan data jumlah tenaga kerja.

Data bahan baku menggunakan informasi data bahan baku dan bahan penolong baik yang berasal dari dalam negeri dan luar negeri. Jumlah nilai bahan baku (domestik dan impor) tersebut dideflasikan dengan menggunakan total indeks harga perdagangan besar yang diberlakukan sama untuk semua perusahaan. 
Sumber daya energi yang digunakan sebagai input produksi menggunakan informasi dari bahan bakar dan pelumas serta tenaga listrik. Kedua energi ini terlebih dahulu diriilkan sebelum diagregasi menjadi satu satukomposit energi. Deflator yang digunakan pada bahan bakardan pelumas adalah indeks harga perdagangan besar Indonesia menurut jenis masingmasing (premium, minyak tanah, solar, minyak diesel, minyak bakar, dan pelumas). Sedangkan untuk tenaga listrik menggunakan deflator dari subsektor listrik di PDB sektoral.

Data yang digunakan mencakup 49 subsektor dengan total perusahaan sebanyak 3.295 buah. Rangkuman data dan sebaran sampel perusahaan lintas sub sektor diuraikan pada Tabel 2 dan Tabel 3.

\begin{tabular}{|c|c|c|c|}
\hline \multicolumn{4}{|c|}{$\begin{array}{c}\text { Tabel } 2 \text { Rangkuman Data yang Digunakan dan Perbandingan Deflator } \\
\text { yang Digunakan dengan Penelitian Terdahulu }\end{array}$} \\
\hline Variabel & Data SIBS yang Digunakan & $\begin{array}{l}\text { Deflator yang Digunakan } \\
\text { Penelitian Ini }\end{array}$ & $\begin{array}{l}\text { Deflator yang Digunakan } \\
\text { Penelitian Ikhsan (2007) }\end{array}$ \\
\hline $\begin{array}{l}\text { Tenaga } \\
\text { Kerja }\end{array}$ & Jumlah tenaga kerja & - & \\
\hline Kapital & $\begin{array}{l}\text { Modal Tetap, meliputi tanah, } \\
\text { gedung, mesin dan } \\
\text { perlengkapan, kendaraan, dan } \\
\text { lainnya }\end{array}$ & $\begin{array}{l}\text { Deflator PMTB dalam PDB } \\
\text { Penggunaan (BPS) }\end{array}$ & $\begin{array}{l}\text { Deflator jasa dalam PDB } \\
\text { dan IHPB mesin (kecuali } \\
\text { produk elektronik), } \\
\text { peralatan transportasi, } \\
\text { bangunan residensial \& } \\
\text { non-residensial (BPS) }\end{array}$ \\
\hline $\begin{array}{l}\text { Bahan } \\
\text { Baku }\end{array}$ & $\begin{array}{l}\text { Bahan Baku dan Bahan } \\
\text { Penolong, baik dalam negeri } \\
\text { maupun impor }\end{array}$ & - IHPB Total (BPS) & $\begin{array}{l}\text { - IHPB impor untuk input } \\
\text { bahan baku impor (BPS) }\end{array}$ \\
\hline Energi & $\begin{array}{l}\text { Bahan Bakar dan Pelumas } \\
\text { (meliputi: Bensin, Solar, } \\
\text { M.tanah, batubara, Gas, } \\
\text { LPG, Pelumas, dan bahan } \\
\text { bakar lainnya); } \\
\text { - Tenaga Listrik (Net) }\end{array}$ & $\begin{array}{l}\text { - Bahan bakar dan pelumas : } \\
\text { IHPB Solar (BPS) } \\
\text { - Tenaga listrik: Deflator } \\
\text { Sektor Listrik dalam PDB } \\
\text { Penawaran (BPS) }\end{array}$ & $\begin{array}{l}\text { Data harga listrik \& bahan } \\
\text { bakar yang dipublikasi } \\
\text { oleh Kementrian } \\
\text { Pertambangan dan } \\
\text { Energi }\end{array}$ \\
\hline Output & $\begin{array}{l}\text { Produksi (Barang yang } \\
\text { dihasilkan) }\end{array}$ & $\begin{array}{l}\text { - IHPB berdasarkan masing- } \\
\text { masing jenis industri (BPS) }\end{array}$ & - 4 digit IHPB (BPS) \\
\hline
\end{tabular}




\begin{tabular}{|c|c|c|c|c|c|}
\hline \multicolumn{6}{|c|}{$\begin{array}{c}\text { Tabel } 3 \\
\text { Jumlah Sampel Penelitian Berdasarkan Subsektor }\end{array}$} \\
\hline KKI 3 & Sub Sektor Industri & Jumlah & KKI 3 & Sub Sektor Industri & Jumlah \\
\hline 151 & Pengolahan\&pengawetan daging, ikan\&minyak makan & 213 & 264 & Barang2 dari semen\&kapur & 33 \\
\hline 152 & Susu\&makanan dr susu & 8 & 265 & Barang dari marmer, batu\&granit & 15 \\
\hline 153 & Penggilingan padi, biji2an\&makanan & 133 & 266 & Barang dari asbes & 7 \\
\hline 154 & Makanan lainnya & 504 & 269 & Barang Galian Bukan Logam Lainnya & 8 \\
\hline 155 & Minuman & 42 & 271 & Penggilingan besi dan baja & 25 \\
\hline 160 & Pengolahan tembakau & 105 & 272 & Penggilingan non-besi & 13 \\
\hline 171 & Pemintalan & 176 & 273 & Pengecoran & 12 \\
\hline 172 & Pertenunan tekstil & 49 & 281 & Konstruksi Bangunan & 20 \\
\hline 173 & Rajut & 38 & 289 & Bahan Bangunan & 116 \\
\hline 174 & Kapuk & 25 & 291 & Alat2 berat & 45 \\
\hline 181 & Pakaian jadi dari tekstil\&kulit & 160 & 292 & Mesin2 & 12 \\
\hline 191 & Barang dari kulit & 26 & 293 & Peralatan rumah tangga & 33 \\
\hline 192 & Alas Kaki & 47 & 311 & Motor\&Mesin Listrik & 10 \\
\hline 201 & Kayu gergajian & 56 & 312 & Panel\&Pengontrol Arus Listrik & 6 \\
\hline 202 & Kayu Olahan & 103 & 313 & Kabel Listrik\&Telepon & 12 \\
\hline 210 & Kertas & 89 & 315 & Lampu & 6 \\
\hline 221 & Barang dari kertas & 114 & 319 & Peralatan Listrik lainnya & 8 \\
\hline 232 & Pengilangan minyak bumi & 8 & 323 & Radio, Televisi, Alat2 Rekaman Suara \& Gambar & 8 \\
\hline 241 & Bahan kimia & 79 & 331 & Perlengkapan Kedokteran & 7 \\
\hline 242 & Barang2 dr bahan kimia & 140 & 342 & Karoseri Kendaraan Bermotor Roda 4/Lebih & 19 \\
\hline 251 & Karet\&hasil2nya & 117 & 343 & Perlengkapan\&Komp. Kend. Bermotor Roda 4/Lebih & 40 \\
\hline 252 & Plastik\&hasil2nya & 226 & 359 & Sepeda Motor, sepeda\&becak & 31 \\
\hline 261 & Kaca & 11 & 361 & Furniture & 172 \\
\hline 262 & Porselin & 20 & 369 & Pengolahan Lain & 83 \\
\hline 263 & Barang2 dari tanah liat & 65 & & & \\
\hline
\end{tabular}

\section{HASIL DAN ANALISIS}

Bagian pertama dalam bab ini memaparkan hasil perhitungan pertumbuhan TFP secara agregat, kemudian dekomposisi komponen pembentuknya. Selain menganalisis keseluruhan tahun pengamatan (2000-2009), analisis akan memisahkan 2 (dua) periodisasi, yaitu 2000-2004 dan 2005-2009. Penjelasan agregat industri tersebut akan dilanjutkan ke analisis lebih rinci berdasarkan subsektor. Analisis subsektor industri dalam hal technical change dan efficiency change dilakukan dengan mengelompokkan subsektor industri ke dalam 4 (empat) kuadran.

\subsection{TFP Agregat Industri Pengolahan}

Dengan menggunakan pembobotan berdasarkan share output masing-masing subsektor industri terhadap total output, diperoleh rata-rata tertimbang pertumbuhan TFP untuk keseluruhan industri. Secara rata-rata TFP sepanjang 2000-2009 meningkat sekitar 7,44\% per 
tahun. Dekomposisi berdasarkan komponennya, sumber pertumbuhan TFP didominasi berasal dari pertumbuhan technical change, disusul economic scale change, dan efficiency change. Artinya, secara rata-rata, sepanjang periode 2000-2009 perusahaan-perusahaan sampel lebih banyak mengandalkan penggunaan teknologi baru dan bergerak menuju optimal scale.

\begin{tabular}{|c|c|c|c|c|}
\multicolumn{5}{|c|}{$\begin{array}{c}\text { Tabel 4 } \\
\text { Pertumbuhan TFP Agregat Industri dan Komponennya }\end{array}$} \\
\hline \multirow{2}{*}{ Periode } & $\begin{array}{c}\text { Total Factor } \\
\text { Productivity Growth }\end{array}$ & $\begin{array}{c}\text { Technical } \\
\text { Change }\end{array}$ & $\begin{array}{c}\text { Efficiency } \\
\text { Change }\end{array}$ & $\begin{array}{c}\text { Economic Scale } \\
\text { Change }\end{array}$ \\
\hline $2000-2009$ & 7,44 & 3,86 & 1,71 & 2,25 \\
$2000-2004$ & 7,83 & $-3,52$ & 8,15 & 6,98 \\
$2005-2009$ & 6,89 & 11,20 & $-2,19$ & $-1,12$ \\
\end{tabular}

Apabila periode pengamatan dipecah ke dalam 2 periode, pertumbuhan TFP mengalami perlambatan di periode 2005-2009 dibandingkan dengan periode 2000-2004. Dalam dua periode ini terdapat perbedaan penting sumber utama pertumbuhan TFP. Bila pada 2000-2004 sumber pertumbuhan TFP adalah efficiency change, maka pada 2005-2009 sumber utamanya adalah technical change.

Pada periode 2000-2004, efficiency change lebih dominan mendorong pertumbuhan TFP. Hal ini terkait dengan kondisi perekonomian Indonesia saat itu yang masih berada dalam proses konsolidasi di berbagai bidang pascakrisis keuangan 1997/1998, termasuk diantaranya adalah pembenahan iklim investasi agar kepercayaan investor dan dunia usaha kembali meningkat. Dalam periode tersebut, di tengah permintaan domestik dan kegiatan investasi yang masih lemah, perusahaan meningkatkan produktivitasnya melalui efisiensi proses produksi.

Beberapa contoh upaya efisiensi proses produksi yang dilakukan perusahaan adalah perbaikan metode penggunaan bahan baku agar mengurangi bahan baku yang terbuang percuma, perbaikan layout produksi agar perpindahan antar stasiun kerja lebih singkat, penyelarasan alur kerja antar tempat kerja (konsep pull system) agar mengurangi penumpukan produk setengah jadi di antara stasiun kerja, dan penerapan konsep Lean Manufacturing agar mengurangi waktu idle produk setengah jadi di antara stasiun kerja. Pada periode ini, technical change yang menurun dapat diartikan sebagai penurunan production frontier, yaitu menurunnya kemampuan produksi mesin-mesin dan salah satu kemungkinannya adalah akibat terhambatnya proses perejamaan dan penggantian mesin. Terganggunya proses ini diindikasi oleh pertumbuhan investasi (PMTB) dan realisasi PMA dan PMDN yang rendah.

Sebaliknya, pada periode 2005-2009, technical change lebih berperan dalam mendorong pertumbuhan TFP. Hal ini sejalan dengan rata-rata pertumbuhan investasi dan realisasi PMA dan PMDN di periode ini yang relatif lebih tinggi dibandingkan dengan periode sebelumnya 
(Grafik 18 dan 19). Kenaikan investasi secara agregat, serta kenaikan realisasi PMA dan PMDN secara umum membawa teknologi baru.

Pada periode ini, meski technical change mengalami peningkatan, namun efficiency change yang menggambarkan catching up effects justru mengalami penurunan. Dalam beberapa penelitian serupa tentang produktivitas di negara lain, salah satu penjelasan dari turunnya catching up effect di saat technical change meningkat adalah keterbatasan kemampuan sumber daya manusia dalam beradaptasi dengan teknologi baru.

Kemampuan untuk melakukan catching-upeffect yang menurun mengindikasi kurangnya kompetensi tenaga kerja, baik disebabkan oleh tingkat pendidikan maupun tingkat keahliannya yang kurang memadai. Kelemahan ini dapat berdampak terhadap kemampuan sektor industri pengolahan untuk beroperasi secara optimal. Dalam jangka panjang, kelemahan ini berpotensi menyebabkan penanaman modal asing yang masuk ke Indonesia adalah yang berteknologi rendah.

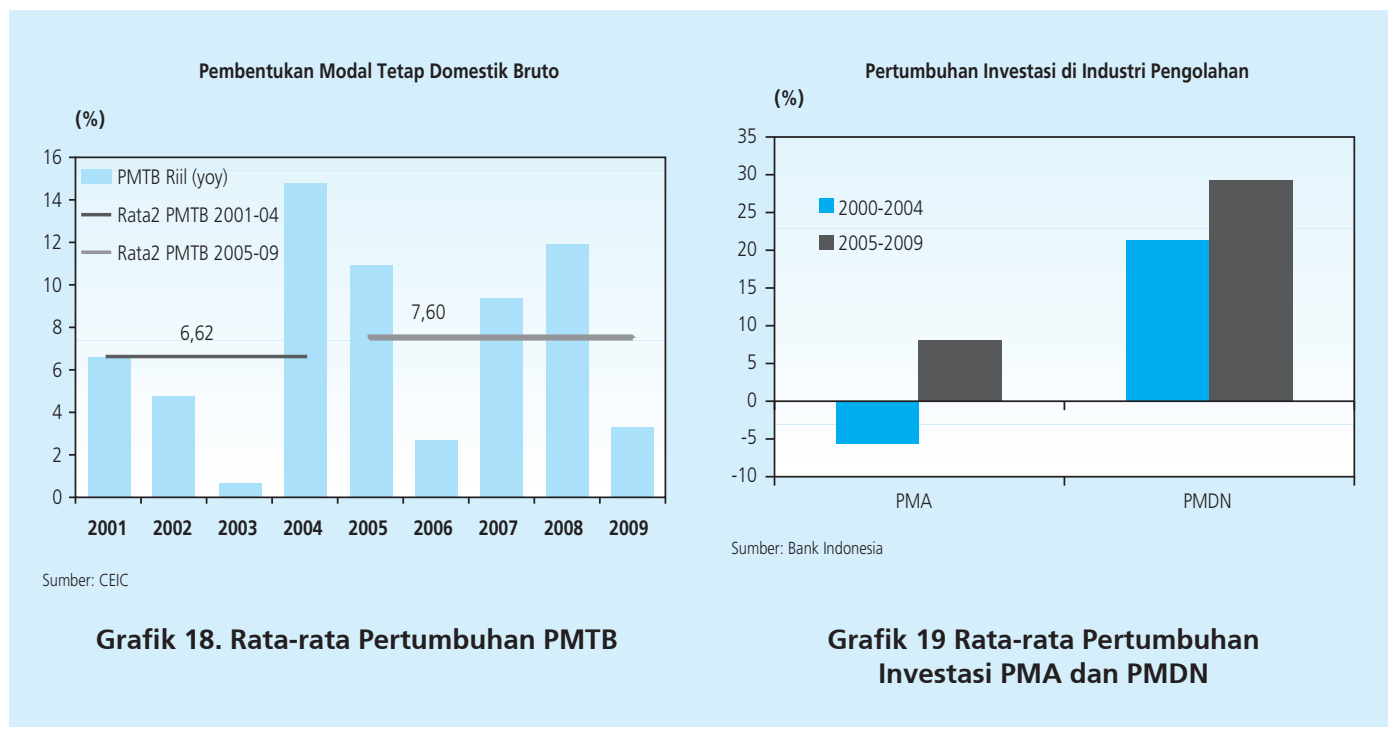

Untuk kasus Malaysia (Mahadevan, 2002) peningkatan technical change tidak diikuti oleh penurunan efficiency change (Grafik 20). Perbedaan rangking Indonesia dengan Malaysia yang cukup jauh dalam pilar-pilar Global Competitiveness Index 2012-2013, khususnya di pilar ke-4 (kesehatan dan pendidikan dasar) dan ke-5 (pendidikan menengah dan pelatihan), diduga menjadi faktor penjelas adanya perbedaan fenomena hubungan komponen TFP tersebut (Tabel 5). 

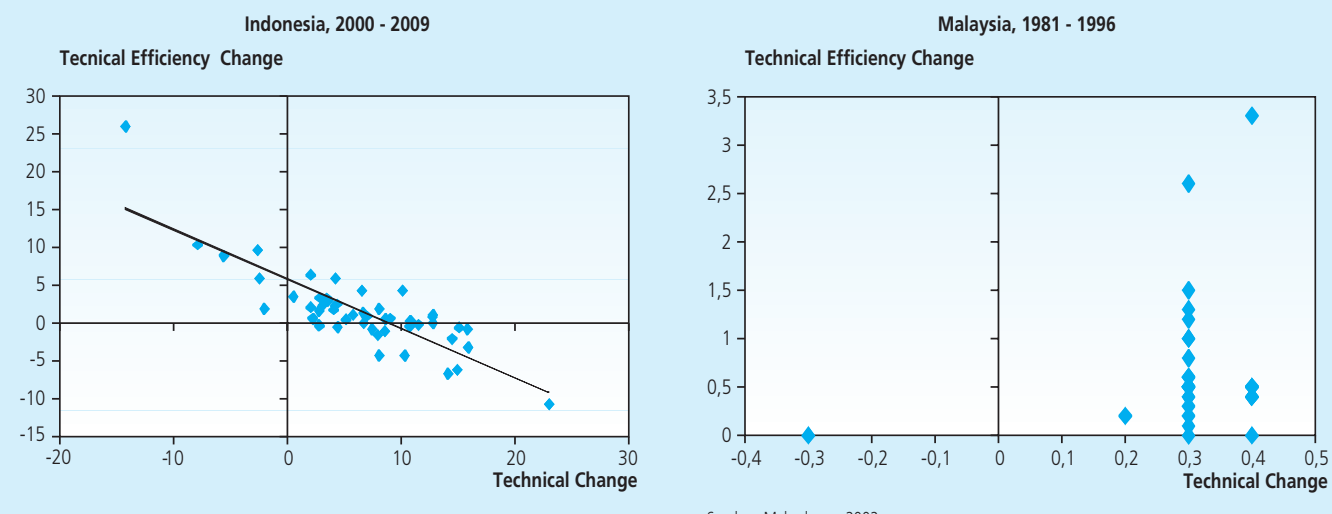

Grafik 20. Perbandingan Hubungan Technical Change dan Efficiency Change Indonesia dan Malaysia

\begin{tabular}{|c|c|c|c|c|c|c|c|c|c|c|c|c|c|}
\hline \multicolumn{14}{|c|}{$\begin{array}{l}\text { Tabel } 5 \\
\text { Peringkat Indonesia berdasarkan Global Competitiveness Index 2012-2013 }\end{array}$} \\
\hline $\begin{array}{c}\text { Peringkat } \\
\text { (terhadap } 144 \\
\text { negara) }\end{array}$ & 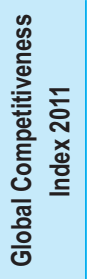 & 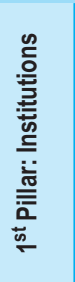 & 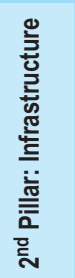 & 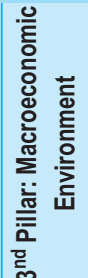 & 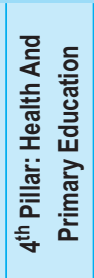 & 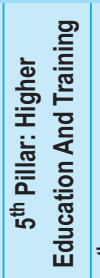 & 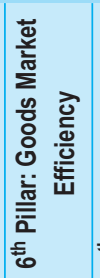 & 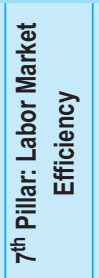 & 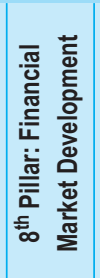 & 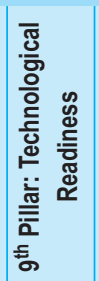 & 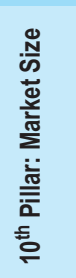 & 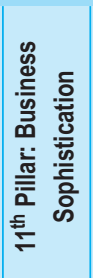 & 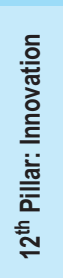 \\
\hline Singapura & 2 & 1 & 2 & 17 & 3 & 2 & 1 & 2 & 3 & 5 & 37 & 14 & 8 \\
\hline Malaysia & 25 & 29 & 32 & 35 & 33 & 39 & 11 & 24 & 6 & 51 & 28 & 20 & 25 \\
\hline China & 29 & 50 & 48 & 11 & 35 & 62 & 59 & 41 & 54 & 88 & 2 & 45 & 33 \\
\hline Thailand & 38 & 77 & 46 & 27 & 78 & 60 & 37 & 76 & 43 & 84 & 22 & 46 & 68 \\
\hline Brazil & 48 & 79 & 70 & 62 & 88 & 66 & 104 & 69 & 46 & 48 & 9 & 33 & 49 \\
\hline Indonesia & 50 & 72 & 78 & 25 & 70 & 73 & 63 & 120 & 70 & 85 & 16 & 42 & 39 \\
\hline Afrika Selatan & 52 & 43 & 63 & 69 & 132 & 84 & 32 & 113 & 3 & 62 & 25 & 38 & 42 \\
\hline India & 59 & 70 & 84 & 99 & 101 & 86 & 75 & 82 & 21 & 96 & 3 & 40 & 41 \\
\hline Filipina & 65 & 94 & 98 & 36 & 98 & 64 & 86 & 103 & 58 & 79 & 35 & 49 & 94 \\
\hline Federasi Rusia & 67 & 133 & 47 & 22 & 65 & 52 & 134 & 84 & 130 & 57 & 7 & 119 & 85 \\
\hline Vietnam & 75 & 89 & 95 & 106 & 64 & 96 & 91 & 51 & 88 & 98 & 32 & 100 & 81 \\
\hline
\end{tabular}

\subsection{TFP dan Komponennya berdasarkan Subsektor Industri}

Apabila dilihat berdasarkan subsektor industrinya, pertumbuhan TFP sepanjang 20002009 terjadi di semua subsektor industri dengan pengecualian subsektor industri lampu (Tabel 6). Technical change menjadi sumber utama pendorong TFP 2000-2009 di sebagian besar subsektor industri, yaitu mencapai sekitar 75\% dari 49 subsektor yang dianalisis. Sedangkan 
efficiency change menjadi sumber utama pertumbuhan TFP di subsektor: Pemintalan; Makanan lainnya, Barang dari Kulit, Alas kaki; Kaca; Barang-barang dari tanah liat; Konstruksi bangunan; Perlengkapan dan komponen kendaraan bermotor roda empat atau lebih; dan Pengolahan lainnya.

Lima subsektor industri yang mengalami rata-rata pertumbuhan TFP pada tahun 20002009 tertinggi secara umum tergolong dalam industri berteknologi tinggi. Kelima subsektor tersebut adalah: Perlengkapan kedokteran; Peralatan listrik lainnya; Motor dan mesin listrik; Alat-alat berat; serta Kabel listrik dan telepon. Sumber pertumbuhan produktivitas di kelima subsektor tersebut adalah technical change.

\section{Tabel 6}

Rata-rata Pertumbuhan TFP dan Komponennya Berdasarkan Subsektor Industri, 2000-2009

\section{Sub Sektor Industri}

Pengolahan \& Awetan daging, ikan \& Minyak Makan

Susu \& Makanan dr Susu

Penggilingan Padi, Biji-bijian \& Makanan

Makanan lainnya

Minuman

Pengolahan tembakau

Pemintalan

Pertenunan tekstil

Rajut

Kapuk

Pakaian Jadi dari Tekstil dan Kulit

Barang dari Kulit

Alas Kaki

Kayu gergajian

Kayu Olahan

Kertas

Barang dari Kertas

Pengilangan Minyak Bumi

Bahan Kimia

Barang-2 dr Bahan Kimia

Karet \& hasil-hasilnya

Plastik \& hasil-hasilnya

Kaca

Porselin

Barang2 dari tanah liat

Barang2 dari Semen dan Kapur

Barang dari Marmer, Batu dan granit

Barang dari Asbes

Barang Galian Bukan Logam Lainnya

Penggilingan Besi dan Baja

Penggilingan non-besi

\begin{tabular}{r|r|r|r}
\multicolumn{1}{c|}{$\begin{array}{c}\text { TFP } \\
\text { Growth }\end{array}$} & $\begin{array}{r}\text { Technical } \\
\text { Change }\end{array}$ & $\begin{array}{r}\text { Eff } \\
\text { Change }\end{array}$ & $\begin{array}{c}\text { Ec. Scale } \\
\text { Change }\end{array}$ \\
8,00 & 7,00 & 0,50 & 0,50 \\
3,00 & 2,20 & $-0,20$ & 1,00 \\
6,50 & 4,10 & 2,20 & 0,10 \\
8,50 & 2,00 & 4,50 & 1,80 \\
10,10 & 8,00 & 0,90 & 1,10 \\
10,20 & 10,70 & 0,60 & $-1,00$ \\
8,10 & $-14,30$ & 9,80 & 14,90 \\
7,70 & 14,90 & $-5,90$ & $-0,40$ \\
8,20 & 6,60 & 0,70 & 0,70 \\
9,20 & 8,60 & 1,20 & $-0,70$ \\
6,60 & 14,10 & $-4,30$ & $-2,40$ \\
3,40 & $-2,50$ & 1,10 & 4,80 \\
10,50 & 4,20 & 3,80 & 2,10 \\
4,40 & 2,70 & 0,20 & 1,50 \\
4,10 & 2,00 & 3,10 & $-1,00$ \\
5,80 & 3,10 & 0,50 & 2,10 \\
9,80 & 23,00 & $-7,20$ & $-3,70$ \\
7,40 & 8,50 & $-0,20$ & $-0,80$ \\
5,50 & 10,30 & $-3,20$ & $-1,10$ \\
6,50 & 7,40 & $-1,30$ & 0,50 \\
5,90 & 4,00 & 0,60 & 1,20 \\
6,80 & 6,70 & 0,60 & $-0,50$ \\
4,20 & 0,50 & 1,60 & 2,00 \\
7,00 & 5,70 & 0,60 & 0,60 \\
6,70 & $-2,70$ & 7,80 & 1,70 \\
6,70 & 3,50 & 0,60 & 2,50 \\
11,10 & 6,50 & 2,40 & 1,90 \\
6,30 & 7,90 & $-0,50$ & $-0,90$ \\
5,60 & 5,10 & 0,50 & 0,00 \\
12,30 & 14,50 & $-1,60$ & $-0,40$ \\
3,90 & 4,40 & $-0,20$ & $-0,30$
\end{tabular}




\begin{tabular}{l|r|r|r|r}
\multicolumn{1}{c|}{ Sub Sektor Industri } & \multicolumn{1}{|c|}{$\begin{array}{r}\text { TFP } \\
\text { Growth }\end{array}$} & $\begin{array}{r}\text { Technical } \\
\text { Change }\end{array}$ & $\begin{array}{c}\text { Eff } \\
\text { Change }\end{array}$ & $\begin{array}{r}\text { Ec. Scale } \\
\text { Change }\end{array}$ \\
Pengecoran & 3,50 & 8,00 & $-3,10$ & $-1,10$ \\
Konstruksi Bangunan & 2,70 & $-5,70$ & 6,80 & 2,10 \\
Bahan Bangunan & 7,00 & 3,40 & 1,40 & 2,00 \\
Alat2 Berat & 13,90 & 12,80 & 1,10 & $-0,10$ \\
Mesin2 & 11,30 & 11,50 & 0,40 & $-0,50$ \\
Peralatan rumah tangga & 7,00 & 4,30 & 0,40 & 2,20 \\
Motor dan Mesin Listrik & 14,40 & 15,10 & 1,10 & $-1,80$ \\
Panel dan Pengontrol Arus Listrik & 13,00 & 12,80 & 0,00 & 0,10 \\
Kabel Listrik dan Telepon & 13,70 & 12,70 & $-0,10$ & 1,00 \\
Lampu & $-0,20$ & $-2,10$ & 0,00 & 2,00 \\
Peralatan Listrik Lainnya & 14,90 & 15,80 & 0,00 & $-0,80$ \\
Radio, Televisi, Alat-2 Rekaman Suara \& Gambar & 11,30 & 10,80 & 0,10 & 0,30 \\
Perlengkapan Kedokteran & 15,00 & 10,10 & 1,00 & 3,30 \\
Karoseri Ranmor Roda 4 Atau Lebih & 9,80 & 9,00 & $-0,80$ & 1,50 \\
Perlengkapan \& Komp. Ranmor Roda 4 Atau Lebih & 6,40 & 2,80 & 3,00 & 0,40 \\
Sepeda Motor, Sepdea dan Becak & 12,20 & 15,90 & $-1,50$ & $-1,70$ \\
Furniture & 2,40 & 2,70 & 0,20 & $-0,40$ \\
Pengolahan Lain & 1,60 & $-8,00$ & 7,20 & 2,90 \\
Weighted Mean & 7,44 & $\mathbf{3 , 8 6}$ & $\mathbf{1 , 7 1}$ & $\mathbf{2 , 2 5}$
\end{tabular}

\subsection{Kuadran Subsektor Industri dan Karakteristiknya}

Subsektor industri dikelompokkan ke dalam 4 (empat) kuadran berdasarkan kategori tingkat technical change, yaitu high dan low4, serta kategori pertumbuhan efficiency change, yaitu positif atau negatif. Kuadran I, yang meliputi subsektor industri yang memiliki technical change tinggi dan efficiency change positif, merupakan kuadran yang terdiri dari subsektor industri dengan produktivitas tinggi, sehingga dapat dianggap sebagai subsektor andalan.

Pada sisi lain, kuadran IV mencakup subsektor industri yang memiliki technical change rendah disertai dengan penurunan efficiency change. Ini merupakan kuadran untuk subsektor industri yang kemajuan produktivitasnya relatif stagnan. Kuadran II memiliki technical change tinggi namun efficiency change negatif, mencakup subsektor industri yang memiliki kemampuan catching up rendah. Peningkatan jumlah subsektor di kuadran II ini akan menjadi tanda tidak mampunya perusahaan berproduksi secara efisien.

Dengan menerapkan metode analisis deskriptif di atas, terlihat bahwa pada periode 20052009 (Tabel 8) jumlah subsektor industri yang berada di kuadran I berkurang dibandingkan periode 2000-2004 (Tabel 7). Sebaliknya, jumlah subsektor industri yang berada di kuadran II pada periode 2005-2009 justru semakin meningkat dibandingkan periode sebelumnya. Berkurangnya jumlah subsektor industri di kuadran I dan meningkatnya jumlah subsektor di

4 Technical change diklasifikasikan ke dalam kategori high dan low berdasarkan nilai mediannya. 
kuadran II mengindikasikan kurangnya pengembangan dan inovasi pada manajerial (tata cara kerja) dalam proses produksi. Hal ini berdampak pada dua hal, pertama, ketidakmampuan perusahaan manufaktur untuk berproduksi pada level potensialnya; dan kedua, lambatnya kemampuan subsektor tersebut untuk beradaptasi dengan teknologi yang semakin berkembang.

Hal di atas berlawanan dengan konsep technical change yang tinggi dapat memberikan prospek peningkatan produktivitas. Implikasi dari semakin bertambahnya jumlah subsektor industri yang berada di kuadran II adalah perlunya pengembangan keterampilan pekerja agar dapat beradaptasi dengan peningkatan teknologi.

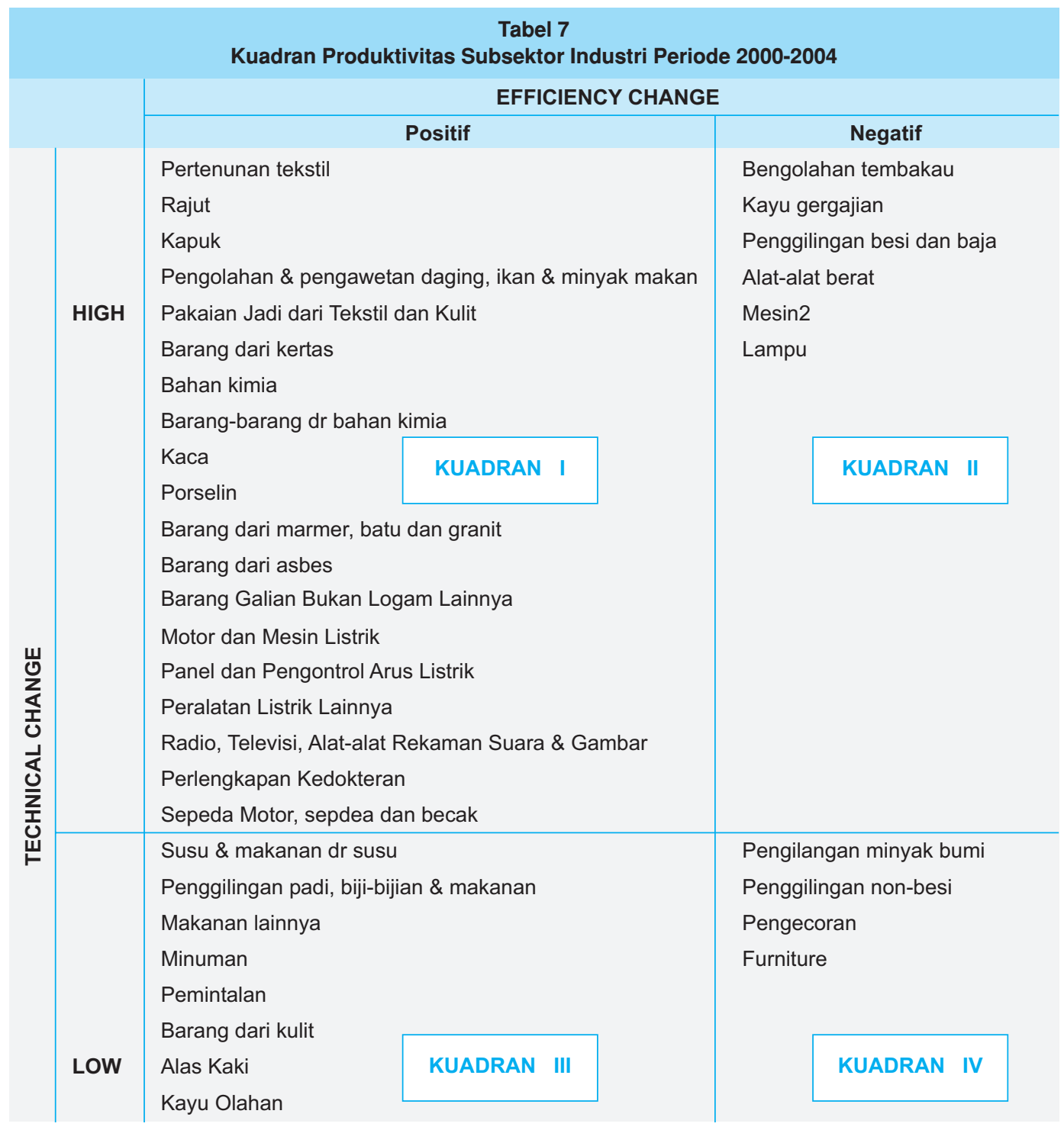




$\left|\begin{array}{|l|l|}\multicolumn{1}{|c}{\text { EFFICIENCY CHANGE }} & \multicolumn{1}{|c}{\text { Positif }} \\ \text { Kertas } \\ \text { Karet \& hasil-hasilnya } \\ \text { Plastik \& hasil-hasilnya } \\ \text { Barang-barang dari tanah liat } \\ \text { Barang-barang dari semen dan kapur } \\ \text { Konstruksi Bangunan } \\ \text { Bahan Bangunan } \\ \text { Peralatan rumah tangga } \\ \text { Kabel Listrik dan Telepon } \\ \text { Karoseri Ranmor Roda Empat atau Lebih } \\ \text { Perlengkapan \& Komp. Ranmor Roda 4 Atau Lebih } \\ \text { Pengolahan Lain }\end{array}\right|$




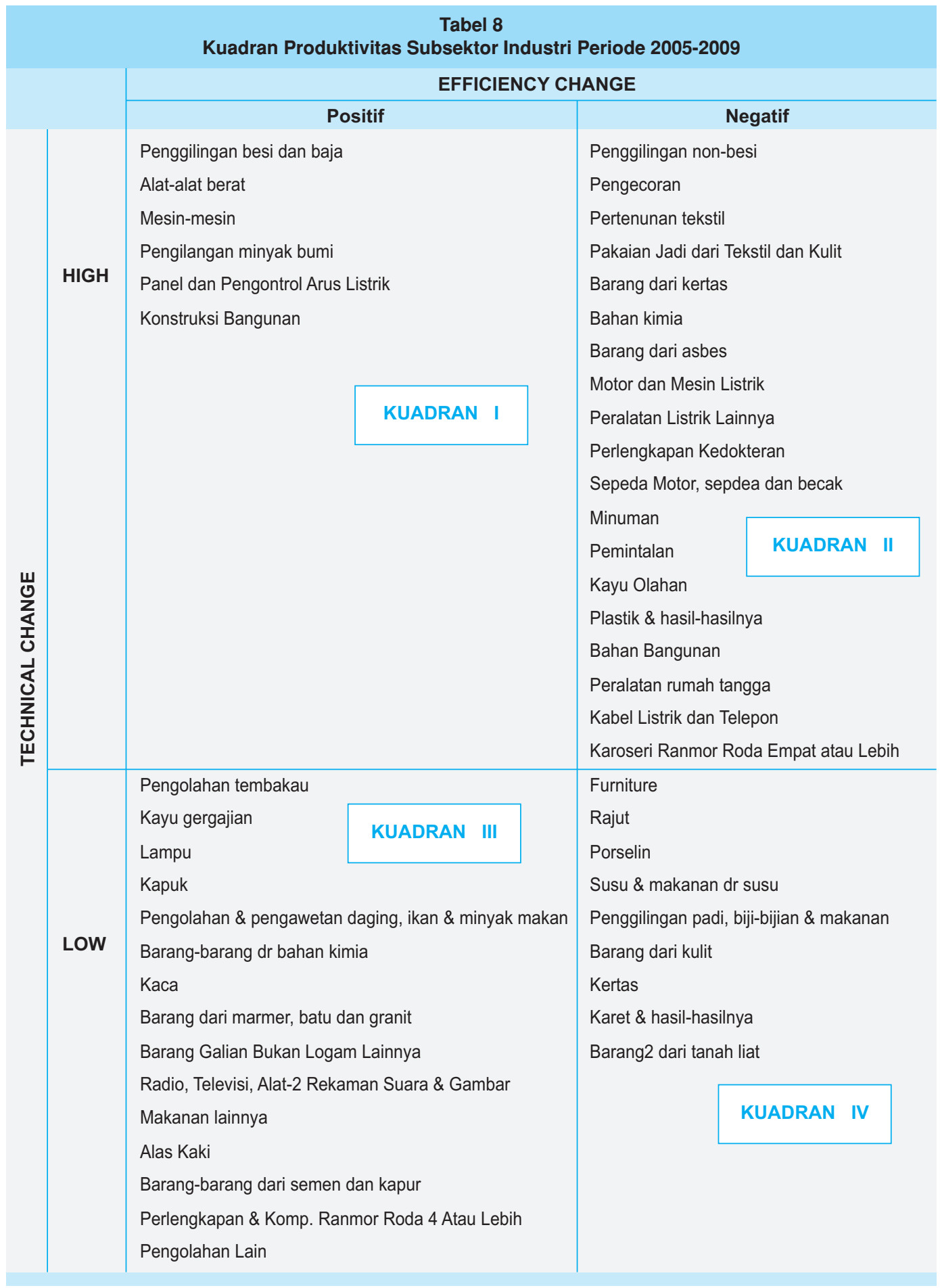


Sebaran sub sektor dalam empat kuadran di atas, dapat dipengaruhi oleh karakteristik perusahaan-perusahaan yang ada pada masing-masing subsektor. Beberapa variabel yang diperoleh dari Survei Industri Sedang dan Besar dan dapat menggambarkan karakteristik masing-masing perusahaan tersebut antara lain adalah intensitas riset dan pengembangan $(R \& D)$; kegiatan inovasi; orientasi penjualan; lokasi perusahaan; penggunaan fasilitas PMA; jenis kepemilikan perusahaan; dan years of schooling. Gambaran ini lebih bersifat indikasi hubungan antar variabel, dan masih memerlukan pengujian formal, namun tidak tercakup dalam penelitian ini.

Tabel 9 di bawah ini merangkum keterkaitan antara masing-masing kuadran dengan beberapa faktor penjelas tersebut.

Terdapat beberapa fakta yang menarik untuk disimpulkan; pertama, penggunaan fasilitas penanaman modal asing berkesesuaian dengan technical change dan efficiency change yang lebih baik, dan ini menempatkan perusahaan-perusahaan yang menggunakan fasilitas tersebut berada di kuadran I. Kedua, pola yang sama juga dijumpai untuk perusahaan yang sebagian atau seluruhnya dimiliki oleh pihak asing. Ketiga, jika perusahaan berlokasi di kawasan industri, maka kecenderungan untuk mendapatkan dukungan infrastruktur akan lebih besar. Selain itu, motivasi bagi perusahaan di dalam kawasan untuk saling belajar dan berinteraksi, akan meningkat. Kedua hal ini akan mendorong peningkatan produktivitas mereka sehingga cenderung berada pada kuadran I, II, dan kemudian kuadran III.

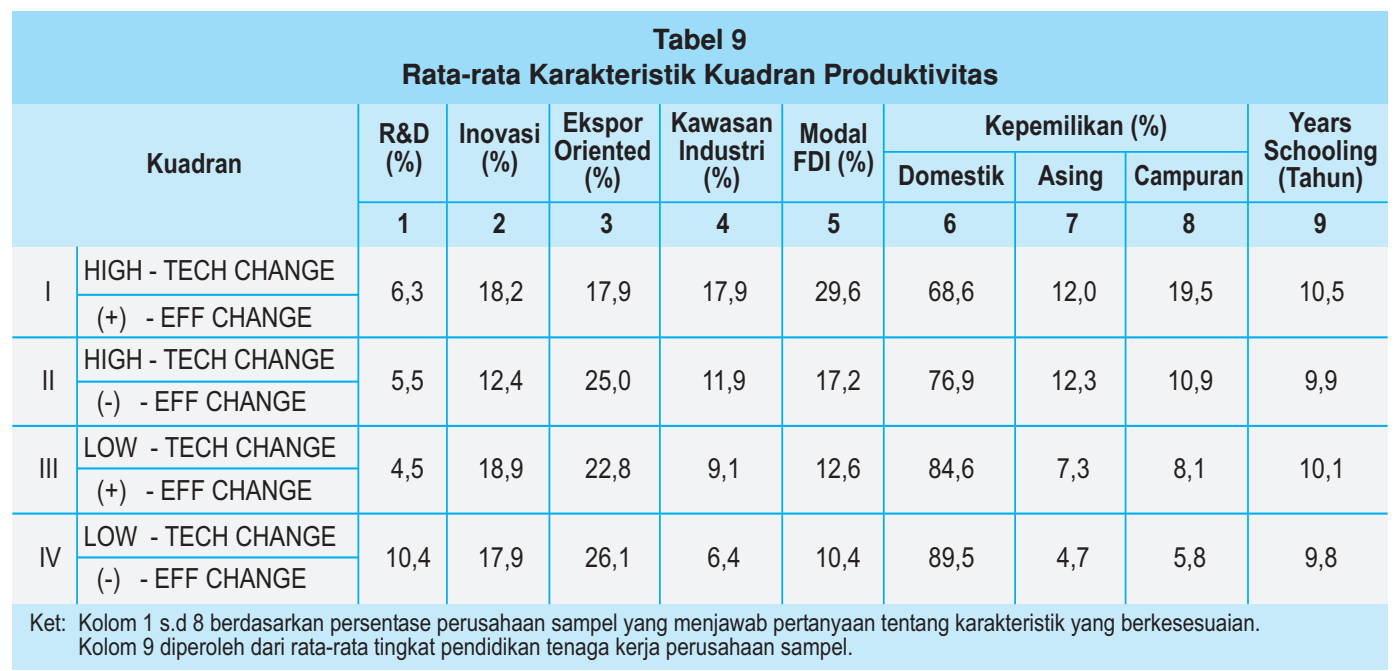




\section{KESIMPULAN}

Penelitian ini menyimpulkan 3 hal penting; pertama, TFP perusahaan besar dan sedang Indonesia secara rata-rata tumbuh 7,44\% sepanjang tahun 2000-2009 dengan sumber pendorong utama yaitu technical change, disusul economic scale change dan efficiency change.

Temuan menarik kedua dari penelitian ini adalah bawah sumber pertumbuhan TFP mengalami pergeseran dalam dua periode pengamatan penelitian.Pada periode 2000-2004, sumber pertumbuhan TFP adalah efficiency change. Sementara itu, pada periode 2005-2009, sumber pertumbuhan TFP bergeser menjadi technical change sejalan dengan kegiatan investasi yang semakin meningkat.

Ketiga, walaupun pertumbuhan technical change menguat di periode 2005-2009, namun kemampuan catching-up (efficiency) yang semakin rendah. Artinya, peningkatan teknologi produksi tidak diikuti oleh kemampuan untuk beradaptasi dengan teknologi yang ada. 


\section{DAFTAR PUSTAKA}

Boediono, DR., "Seri Sinopsis Pengantar Ilmu Ekonomi No.1 Ekonomi Mikro", BPFE, edisi 2, 1999.

Douglas W. Caves, Lauritz R. Christensen and W. Erwin Diewert, 1982, The Economic Theory of Index Numbers and Measurement of Input, Output, and Productivity, Econometrica, Vol. 50, No. 6 (Nov.1982), 1393-1414.

Coelli, Timothy J., et al. (2005), "An Introduction To Efficiency And Productivity Analysis", Springer Science \& Business Media, Inc, edisi kedua.

Coelli t.J. (1996), "A Guide to DEAP Version 2.1: A Data Envelopment Analysis (Computer) Program", Centre for Efficiency and Productivity Analysis (CEPA), Department of Econometrics University of New England, Australia.

Cooper, William W.; Seiford, Lawrence M. and Tone, Kaoru, (2007). "Data Envelopment Analysis", 2nd Edition. Springer.

Direktorat Evaluasi Kinerja Pembangunan Sektoral, (2010), "Perubahan Produktivitas Industri Manufaktur Indonesia dan Faktor-faktor yang Mempengaruhinya: Analisis Panel Data 20002007", Kementerian PPN/Bappenas.

Halim, Rizal Edy, (2010), "Marketing productivity and profitability of Indonesian public listed manufacturing firms: An application of data envelopment analysis (DEA)", Benchmarking: An International Journal, Vol. 17 Iss: 6 pp. 842-857.

Kumbhakar, Subal C. and Lovell, C.A.Knox, (2004). "Stochastic Frontier Analysis". Cambridge University Press.

Ikhsan, Mohamad (2007), "Total Factor Productivity in Indonesian Manufacturing: A Stochastic Frontier Approach", Global Economic Review Vol. 36, No. 4, pp. 321-342.

Mahadevan, Renuka (2002), "A DEA Approach to Understanding the Productivity Growth of Malaysia's Manufacturing Industries", Asia Pacific Journal of Management, 19, 587-600.

Pindyck, Robert S., dan Daniel L. Rubinfeld, "Microeconomics", edisi ke-4, Prentice-Hall, 1998.

Prabowo, Handono E.T., dan Cabanda, Emilyn (2011), "Stochastic Frontier Analysis of Indonesian Firm Efficiency: A Note", International Journal of Banking and Finance, Volume 8; Iss. 2, Article 5.

Saputra, Putu Mahardika Adi, (2011), "Analysis of Technical Efficiency of Indonesian Manufacturing Industries: An Application of DEA", International Research Journal of Finance and Economics, Issue 66. 